\title{
MANAGED CARE AND TECHNOLOGY ADOPTION IN HEALTH CARE: EVIDENCE FROM MAGNETIC RESONANCE IMAGING
}

\author{
Laurence C. Baker
}

Working Paper 8020

http://www.nber.org/papers/w8020

\author{
NATIONAL BUREAU OF ECONOMIC RESEARCH \\ 1050 Massachusetts Avenue \\ Cambridge, MA 02138 \\ November 2000
}

I thank Randall Ellis, Alan Garber, William Vogt, anonymous referees, and many seminar participants for helpful comments. Susan Wheeler provided invaluable assistance with data analysis. This project was supported by a grant from the Robert Wood Johnson Foundation's Health Care Financing and Organization Program. Address correspondence to the author at the Department of Health Research and Policy, HRP Redwood Building Room 253, Stanford University School of Medicine, Stanford, CA 94305-5405. The views expressed in this paper are those of the author and not necessarily those of the National Bureau of Economic Research.

(C) 2000 by Laurence C. Baker. All rights reserved. Short sections of text, not to exceed two paragraphs, may be quoted without explicit permission provided that full credit, including (C) notice, is given to the source. 
Managed Care and Technology Adoption in Health Care:

Evidence from Magnetic Resonance Imaging

Laurence C. Baker

NBER Working Paper No. 8020

November 2000

JEL No. I1

\section{ABSTRACT}

Increasing managed care activity could influence the adoption and diffusion of new medical technologies. This paper empirically examines the relationship between HMO market share and the diffusion of magnetic resonance imaging (MRI) equipment. Across markets, increases in HMO market share are associated with slower diffusion of MRI into hospitals between 1983 and 1993, and with substantially lower overall MRI availability in and outside of hospitals in the mid and later 1990s. High managed care areas also had markedly lower rates of MRI procedure use. These results suggest that technology adoption in health care can respond to changes in financial and other incentives associated with managed care, which may have implications for health care costs and patient welfare.

Laurence C. Baker Department of Health Research \& Policy HRP Redwood Building, Rm T253

Stanford University

Stanford, CA 94305

and NBER

laurence.baker@stanford.edu 


\section{Introduction}

Among the many questions raised by growth in managed care is the impact it will have on the development, adoption, and use of new medical technologies. The U.S. health care system has been characterized for many decades by rapid technological progress, fueled in part by a reimbursement system that generously payed for the development and use of new advanced therapies (Weisbrod, 1991). Now, however, some fear that growth in managed care is eroding the pillars that supported this system. Managed care has reduced physician and hospital reimbursement in many parts of the United States and moved to limit use of expensive tests and procedures by enrollees, often focusing most intently on spending for new high cost technologies at the most advanced institutions. Reductions in the profitability of new innovations could slow adoption and reduce the overall availability of technologies. This, in turn, could have ripple effects throughout the process of technology development if researchers and developers perceive changes in the markets for new products and scale back their efforts or alter their research and development strategies.

Changes in the availability of new technologies and the rate of technological change could have important implications for the health care system. It is widely believed that the majority of health care cost growth over the past 50 years is due to technological change (Newhouse, 1992; Fuchs, 1996). Rapid technological change also appears to have significantly improved the capacity of medicine to treat disease and thereby substantially improved the wellbeing of patients (e.g. Cutler, McClellan, and Newhouse, 1998, on heart attack patients). Understanding the impact of managed care on technology change is thus important for assessing its impact on spending and patient welfare, as well as for evaluating and optimally designing policies that would influence the future development of managed care. 
This paper investigates the relationship between managed care activity and the adoption of magnetic resonance imaging (MRI) equipment, a good example of a technology that could have been influenced by managed care. MRI is a diagnostic tool for producing high resolution images of body tissues, most frequently the brain and spinal cord. The first prototype MRI machines for human imaging were installed in the United States in 1980 and MRI entered general clinical use in 1982 (Baltaxe and Geokas, 1983, Hillman and Schwartz, 1985). It diffused during the 1980s and 1990s, the period in which managed care came to play a significant role in the U.S. health care system.

MRI has attracted attention, from managed care plans among others, partly because of its high cost. Hospitals or other health care providers that wish to offer MRI typically purchase and install an MRI scanner. ${ }^{1}$ The machines themselves are costly, typically running more than $\$ 1.5$ million for a new imager, and there are often substantial facility modifications that must be made to provide coolant for the magnets and shield surrounding equipment from powerful magnetic fields (Bell, 1996; Steinberg and Evens, 1988). The operating costs of MRI can also be significant. Personnel and maintenance costs can easily amount to $\$ 200,000$ per year for most facilities, and the cost of supplies were estimated to be more than $\$ 100$ per scan in 1995 (Bell 1996). Patient charges associated with MRI procedures vary widely depending on things like the complexity of the images required and physician charges for interpretation, but it is not difficult to run up a total bill of more than $\$ 1,000$ even for a relatively straightforward MRI procedure.

${ }^{1}$ Health care providers that do not purchase their own MRI equipment can make arrangements with other providers who have adopted MRI to obtain services for their patients. Some form explicit agreements that allow for patient referrals. Others, particularly hospitals in rural areas, contract with mobile MRI providers that operate MRI imagers mounted in vehicles that move from place to place. In this paper, I focus on providers that have adopted their own fixed MRI equipment. 
MRI can improve the speed and accuracy with which many diagnoses can be made. For some conditions and patients, though, MRI scans can be viewed as helpful but not necessary. It is sometimes possible to substitute other less expensive procedures like computed tomography (CT) or ultrasound for MRI with arguably limited effects on the quality of the diagnosis. Virtually all insurers cover medically indicated MRI procedures, but health plans concerned about costs have been particularly vigilant about the use of MRI in cases where its benefits are not immediately clear or where other procedures could be substituted.

The next section briefly reviews mechanisms by which managed care could have influenced adoption of MRI. I then turn to the empirical work. Using data on hospital adoption of MRI and data on the overall availability of MRI, I examine MRI diffusion and availability in markets with varying levels of HMO market share. I conclude that managed care was associated with slower diffusion of MRI, particularly in hospitals. With expenditures for the purchase of MRI equipment typically running in the millions of dollars, reductions in adoption should have produced substantial savings. But, achieving these savings may also have entailed reductions in the use of services that benefit patients, which would leave questions about the net welfare effects open. After studying the effects of managed care on adoption patterns, I briefly examine the relationship between HMO market share and the number of MRI procedures performed. The results suggest that increases in HMO market share are strongly associated with declines in the utilization of MRI procedures.

The general patterns and determinants of technology adoption in health care, including the case of MRI, have been widely studied. ${ }^{2}$ The overall impacts of managed care on spending

${ }^{2}$ For general studies of health care technology diffusion see, e.g., Anderson and Steinberg (1984), Baker (1979), Banta (1980), Cutler and McClellan (1996), Fendrick et al. (1994), Globerman (1982), Lee 
and premiums have also been previously examined. ${ }^{3}$ However, there is relatively little work that examines the effects of managed care on technology adoption and use in detail. Cutler and Sheiner (1998) investigated the relationship between state-level HMO market share and the availability of a range of services in hospitals, finding evidence that managed care slowed the diffusion of technologies that were diffusing recently. Baker and Brown (1999) report that managed care reduced the number of mammography providers, but increased the volume of procedures performed at the remaining sites. Baker and Phibbs (2000) report that high HMO market share was associated with slower adoption of neonatal intensive care units between 1980 and 1996. The literature is not unanimous, however. Baker and Spetz (1999) report that managed care activity was not associated with changes in an index of hospital technologies, suggesting that managed care may not slow overall adoption, and Hill and Wolfe (1997) reported mixed effects of managed care on diffusion of a range of technologies in Wisconsin during and after rapid growth in managed care activity. ${ }^{4}$

\section{Managed Care Activity and Technology Adoption}

and Waldman (1985), Romeo et al. (1984), Salkever and Bice (1976), and Russell (1977). For studies specific to MRI, see Hillman and Schwartz (1985, 1986), Teplensky (1993, 1994), Teplensky et al. (1995), and Vogt (1997).

${ }^{3}$ See, e.g., Baker (1997, 1999), Baker and Corts (1996), Chernew (1995), Clement et al. (1992), Feldman et al. (1986), Feldman et al. (1993), Frank and Welch (1985), Goldberg and Greenberg (1979), McLaughlin (1987, 1988), Noether (1988), Robinson (1991, 1996), Welch (1994), and Wickizer and Feldstein (1995).

${ }^{4}$ There have also been some less detailed studies of managed care and technology diffusion. For example, the Technology Marketing Group studied the relationship between HMO market share and utilization of computed tomography (CT), MRI, cardiac catheterization, and nuclear medicine in 53 metropolitan areas (Vanden Brink et al., 1995). The study reported no evidence of a relationship, but used only a single cross section of data and did not control for potentially important covariates. 
"Managed care," for purposes of discussion here, describes a collection of activities health plans can undertake to reduce the high levels of utilization and spending that accompanied unfettered fee-for-service medicine and improve the efficiency of health care delivery. These activities can include a range of things like the use of financial incentives to influence utilization patterns, direct oversight of utilization decisions, selective contracting with preferred physicians and hospitals, and restrictions on patient choices of providers through the use of closed panels and gatekeepers.

Growth in the number and size of health plans using strategies like these could influence technology adoption in several ways. Most straightforwardly, managed care could make it less profitable for hospitals, physician groups, or other providers to adopt new technologies like MRI. Many managed care plans have reduced the amounts that they are willing to pay providers, particularly for expensive services like MRI (Bell, 1996). Patients in managed care plans are also less frequently referred for expensive tests and procedures (Miller and Luft, 1997). Beyond just enrollees in managed care plans, evidence suggests that even fee-for-service patients treated in areas with high levels of managed care activity receive less intensive treatments (e.g. Baker, 1999). Reductions in profitability would tend to slow adoption-virtually all models of technology adoption, including studies of health technologies, suggest that profitability is a key determinant of adoption patterns (e.g. Mansfield, 1968, Reinganum, 1989).

The view that growth in managed care will slow the adoption of new technologies like MRI by reducing profitability is commonly encountered. But, it is not clear that managed care need necessarily slow adoption. If excess profits were earned by providers in the absence of managed care, then growth in managed care that reduced but did not eliminate excess profits need not change provider behavior. In addition, MRI, like most new technologies, is a substitute 
for some services and a complement for others, and a full assessment of the profitability of adoption would incorporate effects on the complete range of services offered by providers. If managed care plans that selectively contract choose providers to include in their network based on the availability of services as well as costs, there may be an incentive to adopt new technologies that are unprofitable in and of themselves in order to help win contracts that will bring in additional patients to other services.

Some literature also stresses the importance of strategic interactions between firms as a determinant of the speed of adoption (see Vogt, 1997, for an overview in the context of MRI diffusion). The specific assumptions and focus of strategic interaction models, and hence their predictions for diffusion processes, vary from model to model. Most models focus on the returns to being the first adopter in a market and the incentive for a firm to delay after a rival has adopted. It is not difficult to believe that managed care could influence the parameters of strategic interactions between firms, although it is difficult to predict the direction of the effect. If the organizations that initially win managed care contracts have an advantage in negotiations in subsequent years, and HMOs value the presence of a new technology in the choice of providers to contract with, growth in managed care could increase the premium associated with first adoption. Rivals of the first adopter might then perceive that they should immediately adopt, before contracting negotiations are completed, leading to an acceleration of adoption in the presence of managed care. On the other hand, rivals could perceive that the opinions of managed care plans with respect to the quality of hospitals will have been formed based on the initial adoption, and that there is little to be gained by subsequent adoption, and choose to postpone adoption, which could raise the mean time to adoption as HMO market share rises. In formal modeling, the direction of strategic effects would depend on the assumptions about the 
preferences of managed care organizations and the expectations of hospitals about the returns to various adoption scenarios, but is increasingly clear that they could play an important role in adoption processes.

While appeals are frequently made to profitability arguments suggesting that managed care should slow the adoption of MRI and other similar technologies, this effect could be mitigated, or even reversed, by other forces. This possibility leaves the direction of the expected net impact of managed care on the timing and extent of MRI adoption ambiguous and open for empirical analysis.

\section{Empirical Approach and Data}

I study the impact of managed care on MRI by comparing MRI diffusion and availability in markets with varying levels of managed care activity. I define markets as Health Care Service Areas (HCSAs). HCSAs are groups of counties constructed to approximate markets for health care services based on Medicare patient flow data (Makuc et al., 1991). There are 802 HCSAs covering the entire continental United States.

I use data on MRI diffusion and availability from three complementary sources. Although MRI machines are operated in a variety of settings, I begin by using AHA survey data on hospital adoption of MRI from 1983 to 1993 to estimate adoption hazard models. These models permit analysis of adoption behavior by a well defined set of potential adopters (hospitals) over 11 years that encompass much of the diffusion period for MRI. They do not capture MRI outside of hospitals, but results below suggest that the primary impact of managed care was on MRI adoption by hospitals, which is captured.

After 1993, the AHA changed the format of its survey questions about MRI, so more 
recent AHA data cannot be used in the adoption hazard models. The more recent surveys do provide some less-detailed information about MRI availability, though, so I use data from 1994, 1996, and 1998 to estimate models of the number of hospitals that offer MRI services per population as a function of managed care activity in different areas. These provide a general measure of the impact of managed care on hospital MRI availability.

The AHA surveys do not provide information about non-hospital MRI, nor do they report the actual number of machines in operation or procedure volume. To obtain this information, I use data from two "censuses" of MRI sites, done in 1993 and 1995, that report the number of machines operating in and outside of hospitals as well as procedure volume by area. These data provide the most detailed information and the best opportunity for examining overall MRI availability and use, albeit only for these two years. I use these data to estimate models of the number of machines per population and procedure use per population in different areas.

Together, these analyses generate a multi-faceted look at MRI diffusion and availability, covering virtually the entire time period that MRI has been used clinically. The hazard models produce information about the effect of managed care on the probability of adoption by an important set of adopters. Estimates of the effect of managed care on the probability of adoption from these models provide clear evidence about the impacts of managed care on the behavior of institutions as reflected in their adoption choices. Results from models of the number of machines per population from the MRI censuses provide useful measures of the overall availability of MRI. From a policy perspective, information about the effect of managed care on the overall availability of MRI equipment per population is valuable since this provides direct information about the effects of managed care on costs and care for the population as mediated through the availability of MRI equipment. On the other hand, models of the overall availability 
of MRI are less clear about the mechanisms by which managed care influences availability since the number of machines reflects the number of candidate adopters, the probability of adoption by candidate adopters, and the number of machines operated by those that adopt, all of which could be influenced by managed care.

\section{AHA Surveys}

Every year, the AHA surveys all of the hospitals operating in the United States. They began asking about the presence of MRI in 1983, immediately following its introduction into clinical use. From 1983 to 1993, the surveys obtained specific information about the presence of MRI equipment in the hospital (see Appendix A for details). To facilitate a hazard-model analysis of adoption over 1983-1993, I constructed a dataset of non-federal general medical and surgical hospitals and children's hospitals in the continental United States that were observed in 1983. Hospitals in rural areas may behave quite differently than hospitals in other areas, so I excluded hospitals in HCSAs with populations under 25,000. This left a sample of 5,344 hospitals in 707 HCSAs. I followed each hospital as far as possible by linking subsequent AHA surveys, and identified hospitals that had adopted MRI (i.e. acquired MRI equipment) and the year of adoption based on answers to the survey questions each year. Appendix A describes the identification of adoption dates from the AHA survey data in detail. Hospitals that could not be followed all the way to adoption or to 1993, including hospitals involved in mergers or acquisitions, were treated as censored.

Beginning in 1994, the format of the questions changed substantially. Hospitals were asked more generally about the availability of MRI services in a variety of settings, and the data do not clearly indicate whether or not the hospital had actually acquired an MRI machine. One 
of the questions used during this time period asked was whether MRI was "owned or provided by the hospital or a subsidiary." Hospitals answering this question in the affirmative need not have adopted MRI in the sense of making a decision to acquire an MRI machine of their own, and they could have provided MRI through a contract with a mobile service that operates MRI imagers on vehicles that move from place to place, but patterns of response to this question by area probably do provide a reasonable approximation of overall hospital MRI availability. I counted the number of non-federal short-term general or children's hospitals in each HCSA in each year that reported owning or providing MRI themselves or through a subsidiary, and I analyze this data for the 707 HCSAs with populations over 25,000.

\section{$\underline{\text { MRI Census Data }}$}

Much more detailed information for two years is available from MRI "censuses" conducted by the Technology Marketing Group (TMG) of virtually all sites providing MRI in the United States, including hospital and non-hospital sites. The first was conducted in late 1992 and early 1993, and the second was conducted in late 1994 and early 1995. For each MRI site, these surveys inquired about a range of items including affiliation (e.g. hospital or non-hospital), number of MRI machines, and procedure volume in the preceding year. Appendix A describes the sampling and survey in more detail. I used this data to compute the number of sites, the number of magnets, and the number of procedures in 707 HCSAs with population over 25,000 in the continental United States.

\section{$\underline{\text { HMO Market Share Data }}$}

I measure the level of managed care activity in each HCSA using data on HMO market 
share, defined as the percent of the population enrolled in HMOs. Although there are many forms of managed care plans that could conceivably exert influence on technology diffusion processes, HMO market share is the only measure for which good geographically detailed data is available for the time period under study here. Moreover, HMOs were by far the most prevalent form of managed care during much of the time that MRI was diffusing, and thus HMO activity probably provides a good proxy for the general level of managed care activity at this time. Even in more recent years, the presence of HMOs is likely to be a good proxy for the overall presence of strong managed care organizations since HMOs tend to use more stringent utilization management than other types of health plans, and have been more aggressive in reducing payments to providers.

At any given time, decisions about whether or not to adopt MRI and the timing of adoption should be a function of the current level of HMO market share and expectations about future levels of HMO market share. Cumulatively, MRI adoption patterns and ultimate MRI availability levels should therefore be functions of actual HMO market share observed, and expectations about future levels of HMO market share held, at all of the points over the course of the diffusion of MRI. No measures of the expectations of physicians and hospital managers are available. Data on HMO market shares by HCSA are available for the early 1990s, and I classify areas based on the average market share over the years 1990-1993. I expect this to be a reasonable proxy for actual and expected HMO market shares during the diffusion of MRI for two reasons. First, areas that had high HMO market shares in the early 1990s also tended to have high market shares in earlier years. For example, using data on Metropolitan Statistical Areas, the correlation between 1990-1993 average market share and 1990 market share is 0.98 . The correlation between 1990-1993 average and 1983 market share is 0.66 . Second, areas that had 
high HMO market shares in the early 1990s also tended to have high growth rates in HMO market shares since 1983 when MRI began diffusing. For example, the MSA-level correlation between the 1990-1993 average and the market share change between 1983 and 1993 was 0.82 . If physicians and hospital managers were able to forecast $\mathrm{HMO}$ growth in their areas with some degree of accuracy, those in areas with high 1990-1993 average market share would also have had higher expected future market share levels during the time period when MRI was diffusing.

The estimates of market share I use were constructed using Group Health Association of America (now the Association of American Health Plans) reports of total enrollment and counties served for all HMOs operating in the United States as of December 31 of each year 1990-1993. Using this data, county-level estimates were constructed by apportioning the enrollment of each HMO among the counties served, and estimates for HCSAs were constructed by aggregating the county-level estimates. The construction of these estimates is described in more detail in Appendix A. The nationwide mean of the 1990-1993 average market share is 16\%. Across HCSAs, average 1990-1993 market shares range from 0 to $50 \%$.

\section{Overall MRI Diffusion and Availability}

Table 1 summarizes adoption of MRI by hospitals in the 1983-1993 AHA survey sample. Over this time period, 1,176 hospitals adopted MRI. Estimates of the cumulative adoption probability derived from Kaplan-Meier estimates of the survival curve (with "survival" indicating non-adoption) rise from 0 to nearly $25 \%$ by 1993.890 of the original 5,344 hospitals are censored before 1993, when all remaining hospitals are censored. The majority of these are censored because they close or merge during the time period, and the large number of hospitals in this category is consistent with overall trends in the hospital industry. 
AHA data from 1994-1998 suggest that MRI continued to diffuse through the late 1990s, although perhaps somewhat more slowly. Figure 1 plots the cumulative adoption probabilities for 1983-1993 from Table 1 along with the share of hospitals in the AHA survey that reported having MRI owned or provided by the hospital or a subsidiary each year for 1994-1998. As a group, AHA survey data from 1994-1998 show more MRI availability than the earlier data, likely because of the more general question about providing MRI and the failure to distinguish fixed MRI equipment from MRI provided by mobile services. Nonetheless, the trend in the 1994-1998 data suggests continued diffusion with a possible slowing of diffusion toward the end of the time period.

Table 2 reports the total number of sites, magnets, and procedures in the 707 HCSAs with populations over 25,000 based on the 1993 and 1995 MRI censuses. ${ }^{5}$ In 1995 , there were 2,484 MRI sites these areas. These sites operated 2,787 magnets, a good indication of the number of MRI machines in operation since each machine typically requires its own magnet. A little over half of the magnets in the U.S. are located in hospitals, ${ }^{6}$ and the remainder are in clinics, physician offices, and other non-hospital locations. About 7.7 million MRI procedures were performed in the United States in 1993 and 8.2 million in 1995.

\section{HMOs and Hospital MRI}

${ }^{5}$ Limiting the analysis to the 707 HCSAs with populations over 25,000 removes very few MRI sites from consideration. In 1993, for example, there were 4 MRI sites, performing about 8,000 procedures per year total, located in the excluded HCSAs.

${ }^{6}$ These data compare favorably with the AHA survey data, which indicated that 1,176 hospitals had adopted MRI by 1993, compared to the MRI census estimate of 1,291 magnets in hospitals in early 1993. One would not expect exact agreement since the AHA data I use exclude some types of hospitals, MRI diffused over time, and some hospitals had more than one magnet. 


\section{Diffusion of MRI into hospitals, 1983-1993}

Hazard models provide a natural framework for studying technology adoption (e.g. Rose and Joskow, 1990, Cutler and McClellan, 1996) by a well defined set of candidate adopters. Denoting the cumulative probability that hospital $i$ has MRI at time $t$ by $F_{i}(t)$ and the density function as $f_{i}(t)$, the hazard is defined as the probability that hospital $i$ acquires MRI at time $t$ conditional on not having acquired MRI up to that point: $\lambda_{i}(t)=f_{i}(t) /\left[1-F_{i}(t)\right]$. I parameterize the hazard using a proportional hazard form: $\lambda_{i}(t)=\lambda_{0}(t) \cdot \exp \left(x_{i}{ }^{\prime} \beta\right)$ where $x_{i}$ denotes covariates that determine the proportionality in the hazard and $\lambda_{0}(t)$ is the baseline hazard.

Define $\gamma(t)=\ln \left(\int_{t-1}^{t} \lambda_{0}(\tau) d \tau\right)$ to be the logarithm of the integrated baseline hazard of

adoption from $t-1$ to $t$. Then the cumulative probability of adopting MRI by time $t$ is given by:

$$
F_{i}(t)=1-\exp \left[-\sum_{s=1}^{t} \exp \left(x_{i}^{\prime} \beta+\gamma(s)\right)\right] .
$$

Denote by $t_{i}{ }^{*}$ the first time in which provider $i$ is observed to have MRI. The probability that MRI was acquired during the interval between time $t_{i}^{*}-1$ and $t_{i}^{*}$ is $F_{i}\left(t_{i}^{*}\right)-F_{i}\left(t_{i}^{*}-1\right)$. The probability that provider $i$ has not acquired MRI by the time of censoring, $T_{i}$, is $1-F_{i}\left(T_{i}\right)$. Letting $\delta_{\mathrm{i}}=1$ for providers that are observed to adopt and $\delta_{\mathrm{i}}=0$ for providers that are censored, the likelihood function for the data is given by:

$$
L(\gamma, \beta)=\prod_{i=1}^{N}\left[F_{i}\left(t_{i}^{*}\right)-F_{i}\left(t_{i}^{*}-1\right)\right]^{\delta_{i}}\left[1-F_{i}\left(T_{i}\right)\right]^{\left(1-\delta_{i}\right)}
$$

The likelihood in (2) is based on differences in the cumulative distribution function and is the correct likelihood for data of the type analyzed here, where the intervals during which adoptions occur are observed, but not the exact timing of the adoption. I maximize the logarithm of this 
likelihood function using standard techniques.

To allow flexible adoption patterns over time, I use a non-parametric baseline hazard (Prentice and Gloeckler, 1978, Meyer, 1990). Hospitals that close, merge, or otherwise drop out of the sample before 1993 without adopting are considered censored. ${ }^{7}$ All of the hospitals in the sample that had not adopted by 1993 were censored at 1993.

HMO market share is categorized into five groups: less than $1 \%, 1$ to $5 \%, 5$ to $15 \%, 15$ to $25 \%$, and $25 \%$ or more. This grouping will both capture non-linearities in the effect of market share and dampen the effects of any measurement error in the market share data. In addition to market share, the models include a set of hospital characteristics that could influence adoption: the average bed size of the hospital over 1983-1993 and dummy variables for hospitals affiliated with medical schools, other teaching hospitals, and childrens hospitals. I also control for a variety of area characteristics. One group of area controls is designed to account for the degree of urbanization and includes the market population and population squared, the area population per square mile and its square, and the percent of the population that lives in an urban area and its square. A second set of variables aims to capture important determinants of health care demand, including population age, education, and income. A third set of area variables controls for characteristics of the area health care system including the number of hospitals per 1,000 population, and the total number of generalists, specialists, and radiologists per 1,000 population. Finally, I include the average 1990 Medicare AAPCC, a general measure of health care costs and

${ }^{7}$ An assumption of these kinds of models is that censoring is independent of adoption hazard, i.e. $F(t)$ is identical for censored and non-censored observations, but hospitals censored for closure or merger could have different adoption hazards than hospitals that are not. To investigate the impact of pooling hospitals and assuming fixed $F(t)$, I reestimated the models below using only hospitals that did not close or merge between 1983 and 1993. The results were almost identical to those reported, suggesting that treating censoring from closure or merger as independent does not significantly bias the results. 
utilization patterns in the HCSA. With the exception of the AAPCC, I measure all of the area variables as of 1993 since these levels seem likely to capture both actual levels of these variables over preceding years and the expectations of hospital managers about trends over 1983-1993.

Column 5 of Table 3 reports means and standard deviations of the independent variables.

The first four columns of Table 3 report estimation results. Results from the basic model (column 1) indicate that increasing HMO activity is associated with substantial reductions in the adoption hazard. The relative hazard for each HMO market share group compared to the lowest market share areas is shown in brackets. Hospitals in the highest market share areas had adoption hazards $28 \%$ lower than hospitals in the lowest market share areas. There appears to be some non-linearity in the effect. Moving to the middle market share groups produces a substantial reduction in the adoption hazard, with slower declines as market share increases further. ${ }^{8}$

To illustrate the effects, Figure 2 plots predicted values of $F(t)$ for markets with less than $1 \%, 5$ to $15 \%$, and $25 \%$ or more market share, holding other covariates fixed at their sample means. The model predicts that by 1993 the cumulative adoption probability was $15.9 \%$ for hospitals in the highest market share areas, compared to $17.0 \%$ for hospitals in the middle market share group, and $21.5 \%$ for hospitals in the lowest market share group.

There may be characteristics of areas that are not accounted for in the models shown in column 1 that confound the effects of HMO market share. For example, some states have

${ }^{8}$ These results are robust to a variety of respecifications, including: (1) allowing all of the nonHMO covariates are allowed to be time-varying; (2) including a control for for-profit hospitals (3) removing the potentially endogenous controls for area number of hospitals and physicians and the AAPCC; (4) including only hospitals in MSAs and measuring HMO market share with either GHAA/AAHP-based MSA market share estimates or Interstudy's published market share estimates; and (5) weighting the regressions by either area population or the area number of hospitals. 
certificate of need programs or other laws that govern the adoption of new medical technologies. Preferences for health care and styles of treatments may also vary geographically. Although including state dummies runs the risk of absorbing exogenous variation in HMO activity, the model shown in column 2 includes them to control for state-level variation in policies and other characteristics. The results continue to indicate that increases in market share are associated with lower adoption hazards, and suggest an effect even stronger than observed in column 1.

Unobserved heterogeneity, particularly that arising from variations in patient or provider preferences for high tech health care, could still exist across areas within states. HMOs may have disproportionately located in areas with low demand for high tech diagnostic imaging because of, say, high levels of health or strong preferences for low-tech medicine among the population. HMOs may also have located in areas with strong preferences for outpatient care, and correspondingly low incentives for hospital adoption. If these kinds of factors were not captured by the covariates included in the models above, estimates of the effect of HMOs would be biased. An approach to this problem is to control for adoption patterns of technologies that diffused before managed care could have played an important role in adoption decisions. If there is some fixed characteristic of high market share areas that causes hospitals located in them to adopt new technologies more slowly than hospitals in other markets, this should be reflected in the diffusion of earlier technologies. Here, I control for the presence of computed tomography (CT) scanners and ultrasound equipment. Both are capital embodied, diagnostic imaging technologies that had diffused to a large degree by the early 1980s. CT in particular is very similar to MRI, except that it began diffusing in 1973. I expect the presence of CT and ultrasound by the early 1980s to reflect the underlying propensities of hospitals in different areas to adopt advanced imaging equipment, independent of the effects of managed care. (An 
additional advantage of controlling for $\mathrm{CT}$ and ultrasound is the potential for substitution across technologies. If hospitals with $\mathrm{CT}$ and ultrasound are less likely to adopt MRI because they do not see the need for another imaging technology, this would be captured in this model.)

Column 3 of Table 3 present results from a model including these variables. Hospitals that adopted CT and ultrasound by 1983 are much more likely to adopt MRI, but controlling for $\mathrm{CT}$ and ultrasound adoption does not have a substantial impact on the HMO market share coefficients. This is consistent with the view that there is not some fixed characteristic of areas that leads hospitals in high market share areas to adopt advanced imaging technologies more slowly than hospitals in other areas. ${ }^{9}$

It might also be that HMOs disproportionately located in areas with strong outpatient delivery systems, where MRI adoption would naturally have occurred more frequently in outpatient settings rather than hospitals. It may also be that HMOs encouraged MRI adoption by outpatient facilities, leading hospitals to adopt less. A way to investigate this is to include the number of non-hospital MRI machines per population in 1993 from the 1993 MRI census as a control in the regressions. This variable may be endogenous, but will absorb fixed area characteristics or HMO effects that led to reduced hospital adoption via increased non-hospital facility adoption. Results, in column 4, are little different, suggesting that the HMO effect is not due to characteristics of area outpatient facilities or HMO diversion of adoption to outpatient

\footnotetext{
${ }^{9}$ Another approach to unobserved heterogeneity is to model it as an additional source of error in the MRI adoption equation so that the hazard becomes $\lambda_{i}(t)=\theta_{i} \lambda_{0}(t) \exp \left(x_{i}^{\prime} \beta\right)$ where $\theta_{i}$ is a random variable capturing the unobserved heterogeneity, assumed to be independent of $x_{i}$ (Heckman and Singer, 1984, Meyer, 1990). Parametric and non-parametric estimation of this model produced results similar to those shown, indicating that the results are not biased by unobserved heterogeneity of this particular form. Note, though, that this does not rule out bias from heterogeneity of other forms and thus is not conclusive proof of the absence of heterogeneity bias.
} 
facilities.

HMOs and Hospital MRI Availability, 1994-1998

I used AHA data from 1994-1998, after the change in the question regime, to compute the number of hospitals that indicated having MRI "owned or provided by the hospital or a subsidiary" per 100,000 population in each area, which should serve as a general measure of MRI availability in the area. Using this data, I estimated cross-sectional OLS models of the form:

$$
M R I H O S P_{j, t} / P O P_{j, t}=\beta_{0}+\beta_{l} H M O_{j}+\beta_{2} X_{j}+\epsilon_{j, t}
$$

where MRI HOSP $P_{j, t}$ denotes the number of hospitals with MRI in area $j$ in year $t, P O P_{j, t}$ denotes the population (in 100,000s), $H M O_{j}$ denotes a vector of dummies for average 1990-1993 HMO market share, ${ }^{10}$ and $X_{j}$ denotes the same set of area covariates used above, augmented by a control for the average number of beds in area hospitals.

Table 4 reports results from estimation of equation (3) for 1994, 1996, and 1998, along with a model estimated using 1993 data from the original question regime for comparison. Increases in HMO market share are associated with reductions in the number of hospitals with MRI per population. In 1993, the results indicate that the highest HMO market share areas had substantially fewer hospitals with MRI per 100,000 population than the lowest market share areas. From 1993 to 1994, the average number of hospitals reporting MRI almost doubled, to 0.670 per 100,000 population. The reductions associated with increasing market share also increased, more than proportionally and, thereafter, the effect of increasing market share became

${ }^{10} 1990-1993$ average market share is used for consistency. In principle, availability in years after 1993 is still a function of the current and expected market shares over the entire diffusion period, which should be captured by 1990-1993 averages. Results using measures for other years are very similar. 
even greater over time. To illustrate the effects of HMO market share on growth in MRI availability over time, I used the regression coefficients to compute predicted levels around the annual national mean values. Results are shown at the bottom of Table 4. They suggest that the number of hospitals with MRI grew substantially between 1994 and 1998 in areas with average market shares under 5\%, but grew much less in areas with higher market shares.

Lower levels of hospital MRI per population could result if high HMO market share were associated with reductions in the number of hospitals, independent of the propensity of hospitals to adopt MRI. One way to investigate the importance of this effect is to examine the fraction of hospitals that have MRI. Coefficients from regressions with the percent of hospitals with MRI as the dependent variable were not always significant and results for the medium market share groups fluctuated over time, but results from these models do consistently suggest that the highest market share areas had lower shares of hospitals with MRI than the lowest market share areas, most strongly in later years. For example, in 1998, when $43 \%$ of hospitals overall reported MRI, the fraction of hospitals with MRI in the highest market share areas was 15 points lower than in the lowest market share areas $(\mathrm{p}<0.01)$.

\section{HMOs and MRI Machines In and Out of Hospitals, 1993 and 1995}

The AHA data provide only part of the picture of MRI availability in the United States since many MRI machines are not in hospitals, and even for hospitals the AHA surveys do not provide information about the number of installed units. The 1993 and 1995 MRI censuses provide data on the number of magnets operated in and outside of hospitals.

I used MRI census data for 707 HCSAs with populations over 25,000 to estimate regressions of the form: 


$$
\begin{aligned}
& M A G_{j, 93} / P O P_{j, 93}=\delta_{0}+\delta_{1} H M O_{j}+\delta_{2} X_{j}+\eta_{j} \\
& M A G_{j, 95} / P O P_{j, 95}=\beta_{0}+\beta_{1} H M O_{j}+\beta_{2} X_{j}+\epsilon_{j}
\end{aligned}
$$

where $M A G_{j, t}$ is the number of magnets in area $j$ in year $t, P O P_{j, t}$ is area population (in hundred thousands), $H M O_{j}$ is average 1990-1993 HMO market share, $X_{j}$ is a vector of covariates, and $\epsilon$ and $\eta$ are error terms. ${ }^{11}$ These models include the same controls for area characteristics and average hospital size used in the hospital MRI availability models.

Results are shown in Table 5. In both years the results suggest that increases in market share are associated with declines in MRI availability. The HMO effect observed in 1995 is stronger and more consistent than in 1993. Since the difference in the estimated HMO effects, $\beta_{1}-\delta_{1}$, is a measure of the effect of HMO market share on the 1993-1995 growth rate in magnets per capita, this suggests that MRI availability grew less quickly in high HMO areas. To illustrate, the bottom portion of Table 5 reports predicted values holding the control variables fixed at their sample means. In low market share areas, MRI sites per 100,000 population rose substantially between 1993 and 1995, while there were many fewer MRI adoptions in high market share areas. ${ }^{12}$ By 1995, the predicted number of magnets per population in the highest market share areas was $30 \%$ lower than in the lowest market share areas.

These results can be used to obtain an estimate of the effect of managed care on the total

${ }^{11}$ Equations (4) and (5) are similar to the differences in differences model that could be estimated using data from both years pooled: $\mathrm{MAG}_{\mathrm{j}, \mathrm{t}} / \mathrm{POP}_{\mathrm{j}, \mathrm{t}}=\gamma_{0}+\gamma_{1} \mathrm{Y}_{1995_{\mathrm{j}}}+\gamma_{2} \mathrm{HMO}_{\mathrm{j}}+\gamma_{3} \mathrm{HMO}_{\mathrm{j}} * \mathrm{Y}_{1995_{\mathrm{j}}}+\gamma_{4}$ $\mathrm{X}_{\mathrm{j}}+v_{\mathrm{j}, \mathrm{t}}$ where $\mathrm{Y} 1995$ is a dummy for observations from 1995. The specification in (4) and (5) relaxes the assumption that the error terms $v$ are iid, allowing for separate distributions for 1993 and 1995 . As a practical matter, the effect on the results is minimal.

${ }^{12} \mathrm{~A}$ natural question is the impact of managed care on the average number of magnets per site. Regressions using the number of sites per population as the dependent variable produced very similar coefficients, suggesting that increases in HMO market share are not associated with changes in the average number of magnets per site on average. 
number of MRI scanners in use. Using results from the 1995 model (column 2), I simulated the total number of magnets that would be in operation in 1995 if all market areas had market shares of $<1 \%$, and, correspondingly, 0.928 scanners per 100,000 population. By this calculation, there would have been 3,255 MRI machines in operation in $1995,468(17 \%)$ more than the 2,787 actually observed.

Including state dummies as a control for state policies and state-level sources of unobserved heterogeneity produces consistent results. For example, with state dummies the 1995 coefficient for areas with average $1990-1993$ market share 15 to $25 \%$ is -0.172 (s.e. $=0.111$ ) and the coefficient for areas with market share of $25 \%$ or more is -0.223 (s.e. $=0.137$ ). Adding in the number of area hospitals with CT and ultrasound in 1983 as controls for area adoption of earlier technologies has almost no impact on the coefficients.

The effect of managed care is centered in hospitals. Columns 3-6 of Table 5 report results from regressions in which the dependent variables are the number of hospital magnets (columns 3 and 4) and non-hospital magnets (columns 5 and 6) per population. Increases in HMO market share are associated with strong reductions in the number of hospital magnets in both years, with stronger effects in 1995. The effect on non-hospital magnets is much weaker. Mechanically, the coefficients from hospital and non-hospital magnet models in each year must sum to that year's coefficient for total magnets reported in columns 1 and 2, so that columns 3-6 can be regarded as a decomposition of the total effect. As such, it suggests that the great majority of the observed effect of HMO market share on MRI availability came about through effects on hospitals.

This is perhaps not surprising given the tendency of managed care organizations to promote the use of outpatient health care over inpatient care. Not only may reduced demand for 
inpatient services directly reduce the returns a hospital would receive from owning an MRI

machine, but the more general squeeze that managed care has put on hospital finances may make also it more difficult for hospitals to obtain the resources required to purchase MRI equipment.

On the other hand, managed care may have encouraged more demand for outpatient services and increased the profitability of owning MRI for physicians offices, clinics, and other outpatient sites.

\section{MRI Utilization}

Reductions in adoptions could reduce patient access to MRI equipment. ${ }^{13}$ Managed care could also directly reduce utilization, even given a fixed number of MRI machines. I investigate the impact of HMO market share on MRI procedure use using models analogous to those estimated for magnets per population. Procedure volume data are derived from the 1993 and 1995 MRI censuses, which asked sites to indicate their total annual procedure volume in the preceding year. I include procedures from sites with fixed equipment and sites contracting with mobile services. Regression results are presented in Table 6. Increases in HMO market share are associated with substantial reductions in total procedure use in both 1992 and 1994, with stronger effects in 1994. Areas with market shares of $25 \%$ or more performed more than 800 fewer procedures per 100,000 population than areas with $<1 \%$ market share, a reduction of $31 \%$ for an area with average characteristics. As with magnets, the declines in procedure utilization are

\footnotetext{
${ }^{13}$ Technically, reductions in the number of sites with fixed MRI equipment need not reduce the number of sites at which MRI is available since providers can contract with mobile MRI services. HMOs could have inhibited adoption of MRI but induced contracting with mobile services, which is typically cheaper. To investigate, I estimated models of the number of sites using mobile providers per 100,000 population from the MRI censuses, and found no significant relationship with HMO market share. This suggests that reductions in fixed MRI were not offset by increases in mobile service use.
} 
largest in hospitals, and there is little evidence of an effect managed care on non-hospital procedure use.

One way to view procedure data is as an additional measure of diffusion. By this measure, HMO market share is associated with sharp reductions in diffusion, consistent with those identified by looking at the number of magnets per population. Procedure data can also serve as an indicator of impacts on patient care. It is clearly not the case that the same number of patients receive MRI in high managed care areas as in low managed care areas, which raises questions about the value of the procedures foregone. MRI is typically not a technology that itself saves lives, but, among other things, it can improve therapy choice, speed up treatments, and ease patients worries about the presence of serious health conditions, so reductions in procedure use may offset at least some of the welfare gains from savings due to foregone adoptions.

In both 1993 and 1995, the reduction in procedure volume associated with increasing market share is about the same size as the reduction in magnets, so that on average the number of procedures per magnet stays about the same with increases in market share. This is interesting in that it suggests managed care activity has not increased the efficiency with which MRI machines are used, a goal which would likely be furthered by increasing the number of procedures per machine. Note though, that the number of magnets may change more slowly than procedure use and may not have reached equilibrium, and that a lack of change in overall procedures per magnet could occur even if managed care plans concentrate their patients at efficient centers with high volume, were they also to leave other centers with reductions in volume so that the overall mean is not changed. 


\section{Conclusions}

Data from AHA surveys and from two MRI censuses indicate that increases in HMO activity are associated with slower diffusion of MRI equipment and lower overall MRI availability. This is consistent with the view that changes in incentives brought about by managed care can have important impacts on technology diffusion in health care.

Since MRI is still diffusing, it is probably too early to say for sure that the equilibrium levels of MRI will be lower in high managed care areas, although that would be a natural outcome of the patterns observed so far. In particular, evidence from the most recent AHA surveys does suggest a general slowing in MRI diffusion in the late 1990s, coupled with substantially reduced MRI availability levels in high managed care areas, consistent with the patterns one might expect if managed care were to bring about lower equilibrium availability levels.

Since technology advancement is thought to be one of the most important drivers of health care costs, this suggests that managed care may be able to influence costs by changing technology diffusion patterns. In the case of MRI, some savings would have accrued from foregone adoptions. Results from models using the MRI census data produced a rough estimate of 468 fewer adoptions due to managed care. Since MRI installations often cost \$1 million or more, this would suggest savings on the order of $\$ 500$ million from foregone adoptions. I also found reduced procedure use in high managed care areas, which would generate additional savings.

These results do not distinguish long term impacts on cost growth rates from one-time savings that do not lower growth rates. Reductions in adoption and frequency of use for any single technology may only produce one-time savings. To substantially impact cost growth rates, 
managed care would have to slow the pace of development and adoption of many new technologies, or persistently limit the spread of a range of technologies to new conditions and patients. The fact that managed care can influence adoption and use of MRI leaves open the possibility that it might be able to do so for other technologies as well, although the extent to which these effects can be extrapolated to other technologies is not completely clear. In the field of diagnostic imaging, there are other diffusing technologies that are not unlike MRI, including PET and SPECT scanners, which might be affected in similar ways. However, MRI differs in important ways from other new technologies like genetic screening procedures. Further research on other technologies and on other aspects of technology development and use are needed to fully evaluate the long-term effects of managed care.

A full assessment of the implications of managed-care-induced changes in MRI adoption and use must balance welfare gains from savings against any offsetting changes in patient care or health outcomes. The fact that managed care is associated with reductions in procedure use suggests that further attention be paid to the value of MRI procedures foregone in markets with high HMO market shares benefit patients, which may have benefitted patients. Managed-careinduced changes in technology adoption also warrant attention for the impact they could have on future technology development. If researchers and developers alter their efforts in response to managed care, the future direction and extent of new developments in medical technology could be altered. This could have potentially important impacts on patient welfare, although it is not clear whether one should expect any such changes to be welfare increasing or decreasing, and it may be very difficult to empirically determine. 


\section{Appendix A: Additional Information About the Data}

$\underline{\text { AHA Data }}$

Beginning with the 1983 survey, the AHA has used four different sets of questions to inquire about the presence of MRI. In 1983-1989, the AHA survey asked hospitals whether they had hospital-based MRI, MRI was provided by another hospital or provider, or whether MRI was not available. Some hospitals may offer MRI through a contract with a mobile service that operates equipment mounted on vehicles that move from place to place. In 1990, the survey retained the original question and added a question asking hospitals that indicated having hospital-based MRI services whether they used fixed equipment or provided MRI through a contract with a mobile provider. The 1993 survey added to the second question the option for hospitals to say MRI was provided using both fixed and mobile equipment (no hospitals indicated using both). In 1994, the AHA survey changed the question format dramatically, replacing the earlier questions with a series of questions asking whether MRI was "owned or provided by [the] hospital or a subsidiary" or provided by other providers in health systems, networks, joint ventures, or elsewhere in the local community. This change is associated with an increase in the number of hospitals that reported having MRI. My hazard model analysis of adoption over time runs from 1983-1993. Separate analysis of data from 1994-1998 are reported separately in the text.

I used responses to AHA survey questions to identify hospitals that adopted fixed MRI equipment between 1983 and 1993 and the year in which they did so. I considered four definitions of adoption year:

1. Adoption year is the first year in which the hospital says it has MRI (pre-1990) or fixed MRI (post-1990). 
2. Adoption year is the first year of the first consecutive pair of years in which the hospital says it has MRI (pre-1990) or fixed MRI (post-1990). For example, a hospital that said it had MRI in 1985, 1987, and 1988, but not 1986 would be defined to have adopted in 1987. Forcing hospitals to indicating having MRI twice in a row to signify adoption results in the reclassification of a small number of hospitals that indicate having MRI in one year but then say that they do not have it in surrounding years.

3. Adoption year is the first year of the first consecutive pair of years, or triple of years with missing MRI information in the middle year, in which the hospitals says it has MRI (pre1990) or fixed MRI (post-1990). For example, a hospital that said it had MRI in 1985, 1987, and 1989, but said no in 1986 and had missing MRI data in 1988, would be defined to have adopted in 1987.

Some hospitals offer MRI via a contract with a mobile service. These hospitals may have indicated having MRI on the pre-1990 surveys. If so, they would have been counted as adopting fixed MRI. One way to remove some of this measurement error is to note that mobile services were rare before 1986 and that hospitals that adopt fixed MRI rarely revert to using mobile services, leading to definition number four.

4. Same as definition 3, but considers hospitals that adopted in 1986-1989, but who said they had mobile MRI in at least two of the three years 1990-1992 as having had mobile MRI the whole time. For example, a hospital that said it had MRI in 1988 and 1989 but said it had a mobile unit in 1990 and 1991 would not be defined as adopting in 1988. Definition four appears to have the best chance of accurately identifying the year of fixed MRI adoption, and it is the definition used in the paper. Results using the other definitions are generally similar, but statistically weaker in the case of definition 1 . 


\section{$\underline{T M G \text { MRI Censuses }}$}

These surveys designed to contact all of the sites offering MRI in the country. The sampling frames for these surveys were developed using "snowball sample" techniques. An initial set of sites offering MRI was identified from state licensing records, manufacturer sales data, and other sources. These sites were contacted and asked to identify other sites offering MRI in their area. Newly identified sites were similarly contacted, and so on until no new sites were identified. It appears that this technique identified most if not all of the sites providing MRI in the country. Although it is not possible to fully verify the data, they do compare well with the AHA data where applicable. Furthermore, since virtually all sites with fixed MRI equipment are known to state regulators and/or manufacturers, it is very likely that all of the sites with fixed equipment were identified in the sample.

Using this frame, a survey of all identified sites was conducted. Survey questions include whether the site used fixed or mobile equipment, whether the site was a hospital or non-hospital site, the number of fixed magnets at the site, and the number of procedures performed. With extensive follow up, at least some data was obtained for all of the sites surveyed. For the questions of used in the paper, item response rates are generally quite good. Virtually all sites reported whether they used fixed or mobile equipment, and whether they were a hospital or a non-hospital site. Data for the few non-responders were imputed based on previous surveys and responses to other survey questions.

Fixed sites were asked on the survey about the number of magnets they had in operation in each year. Most, but not all, sites provided this information. On the 1995 survey, for example, $86 \%$ indicated the number of magnets in operation. To estimate the total number of magnets in operation throughout the United States, the number of magnets for non-responding 
sites was imputed based on responses to the previous survey (for 1995 non-responders) and responses to other survey questions. Since the vast majority of sites use one magnet, and sites using multiple magnets are relatively well known and identifiable, imputation for non-responding sites is not expected to bias results. I experimented with repeating the analysis of magnets per population using just the markets in which all of the sites reported the number of magnets, and the results were essentially unchanged.

Procedure data was also provided by most, but not all, sites. In 1995, 76\% reported procedure volume. TMG also provided imputed data that filled in procedure volume data for sites that did not report volume on the survey. 51\% of the sites that did not report 1994 procedure volume had reported 1992 volume on the 1993 survey, and missing 1994 data was filled in using 1992 data adjusted for average 1992-1994 changes in volume for sites of the same site type (non-hospital sites, hospitals with less than 200 beds, hospitals with 200-399 beds, and hospitals with 400 or more beds). The remaining missing 1994 cases were filled in using regression imputation that accounted for site type and the number of magnets at the site. 1992 procedure data from the 1993 survey were handled similarly. In analyzing procedures per population, I first used only 331 markets in which all sites reported procedure volume. I then performed analyses using all of the markets in the sample, relying on imputed data for sites that

did not report procedure volume. Results from these two sets of analyses were similar and so, in the interest of presenting as broad a picture as possible, I report data from all markets in the paper.

\section{HMO Market Share Data}

Construction of county-level estimates of HMO market share, which were aggregated to 
the HCSA level for analysis, took place in three steps. First, the total enrollment and service area, specified by county, were obtained for each HMO in the United States. The primary source of information on HMO enrollments and service areas is the National Directory of HMOs, published annually by the Group Health Association of America (GHAA, various years). Each year the GHAA conducts a mail survey, with telephone follow up, of all known HMOs in the country and, among other things, asks their total enrollment and their service area. The results of the survey are published in the annual Directories. Virtually all of the HMOs in the directories indicated their enrollment. In cases where enrollment was not reported, enrollment was determined by reference to subsequent directories and/or telephone contact. Virtually all HMOs indicated the counties that they served, although some did not provide a clear definition of their market area in terms of counties. For these HMOs, market areas were determined by reference to subsequent Directories and/or telephone contact.

The next step was to distribute the enrollment of each HMO among the counties in its service area. Initially, this was done by simply distributing enrollment proportionally to county population. In addition, since HMO enrollment may be concentrated near HMO headquarters or since HMOs may locate their headquarters in areas where their enrollment is concentrated, estimates that incorporate both county population and distance from HMO headquarters were constructed. The correlation between estimates produced by the two methods is approximately 0.97. Estimates that incorporate both population and distance are used here.

Once enrollments had been distributed over service areas, the total number of enrollees in each county was computed by summing over the set of HMOs serving that county. Using the set of county enrollment estimates, market share estimates were computed as the proportion of the population enrolled in HMOs. These estimates were then aggregated to the HCSA level for 
analysis.

To assess the quality of the estimates, I compared them to estimates from some other sources. The correlation between 1990-1993 average market share aggregated to the MSA level and 1996 MSA-level estimates from Interstudy (1997), which have been used by a number of other researchers and are widely viewed as reliable, is 0.71 . The correlation between the 19901993 average and estimates for 51 MSAs based on a 1996 population survey done by the Center for Studying Health Systems Change is 0.82. Finally, the correlation between the 1990-1993 average and MSA-level estimates of the percent of employees enrolled in HMOs based on a 1993 survey of employers in 10 states done by Rand Corporation was 0.68 , despite the fact that the 1990-1993 estimates are for the entire population and the employer-survey estimates are only for employed individuals. These correlations are all quite high, particularly given the variations in the years of the observations and the populations that are represented (e.g. the entire population as opposed to employees). 


\section{References}

Anderson, Gerard F. and Earl P. Steinberg, "To buy or not to buy: Technology acquisition under prospective payment." New England Journal of Medicine, $311: 3$ (July 19, 1984) 182-185.

Baker, Laurence C., "HMOs and fee-for-service health care expenditures: Evidence from Medicare." Journal of Health Economics, 16:4 (August, 1997) 453-482.

Baker, Laurence C., “Association of Managed Care Market Share and Health Expenditures for Fee-For-Service Medicare Patients," Journal of the American Medical Association 281:5 (February 3, 1999) 432-437.

Baker, Laurence C. and Martin L. Brown., "Managed care, Consolidation Among Health Care Providers, and Health Care: Evidence From Mammography," Rand Journal of Economics 30:2 (Summer 1999) 351-374.

Baker, Laurence C. and Kenneth S. Corts, "HMO penetration and the cost of health care: market discipline or market segmentation?" American Economic Review, 86:2 (May, 1996) 389394.

Baker, Laurence C. and Ciaran S. Phibbs, "Managed Care, Technology Adoption, and Health Care: The Adoption of Neonatal Intensive Care” NBER Working Paper 7883, September 2000.

Baker, Laurence C. and Joanne Spetz. "Managed Care and Medical Technology Growth," in Frontiers in Health Policy Research, Volume 2, ed. A.M. Garber, Cambridge, MA: MIT Press. 1999.

Baker, Stephen R., "The diffusion of high technology medical innovation: The computed tomography scanner example." Social Science and Medicine, 13D (1979) 155-162.

Baltaxe, Harold A., and Michael C. Geokas, "Nuclear magnetic resonance," Annals of Internal Medicine 98:4 (April, 1983), 540-542.

Banta, H. David, "The diffusion of the computed technology (CT) scanner in the United States." International Journal of Health Services, 10:2 (1980) 251-269.

Bell, Robert A., "Economics of MRI Technology," Journal of Magnetic Resonance Imaging, 6:1 (January/February 1996) 10-25.

Chernew, Michael, "The impact of non-IPA HMOs on the number of hospitals and hospital capacity." Inquiry, 32:2 (Summer, 1995) 143-154.

Clement, Dolores Gurnick, Phillip M. Gleason, and Randall S. Brown, The Effects of Risk Contract HMO Market Penetration on Medicare Fee-For-Service Costs: Final Report, 
Mathematica Policy Research: Princeton, NJ, December 18, 1992.

Cutler, David M. and Sheiner, Louise, "Managed care and the growth of medical expenditures" Frontiers of Health Policy Research, A.M. Garber, ed., MIT Press (1998).

Cutler, David M., and Mark McClellan, "The Determinants of Technological Change in Heart Attack Treatment" NBER Working Paper \#5751, 1996.

Cutler, David M., Mark McClellan, and Joseph Newhouse, "The Costs and Benefits of Intensive Treatments for Cardiovascular Disease" NBER Working Paper \#W6514, April 1998.

Feldman, Roger, Bryan Dowd, and Gregory Gifford, "The effect of HMOs on premiums in employment-based health plans." Health Services Research, 27:6 (February, 1993) 779811.

Feldman, Roger, Bryan Dowd, Don McCann, and Allan Johnson, "The competitive impact of health maintenance organizations on hospital finances: An exploratory study." Journal of Health Politics, Policy, and Law, 10:4 (Winter, 1986) 675-698.

Fendrick, A. Mark, Jose J. Escarce, Clyde McLane, Judy A. Shea, and J. Sanford Schwartz, "Hospital adoption of laparoscopic cholecystectomy." Medical Care, 32:10 (October, 1994) 1058-1063.

Frank, Richard G. and W. Pete Welch, "The competitive effects of HMOs: A review of the evidence." Inquiry, 22 (Summer, 1985) 148-161.

Fuchs, Victor, "Economics, Values, and Health Care Reform," American Economic Review 86:1 (March 1996) 1-24.

GHAA, National Directory of HMOs. various years, Washington D.C.: The Group Health Association of America.

Globerman, Steven, "The adoption of computer technology in hospitals." Journal of Behavioral Economics, 11:2 (Winter, 1982) 67-95.

Goldberg, Lawrence G. and Warren Greenberg, "The competitive response of blue cross and blue shield to the growth of health maintenance organizations in northern California and Hawaii." Medical Care, 17:10 (October, 1979) 1019-1028.

Heckman, J., and B. Singer, "A Method for Minimizing the Impact of Distributional Assumptions in Econometric Models for Duration Data," Econometrica 52:2 (March 1984) 271-320.

Hill, S.C. and B.L. Wolfe, "Testing the HMO competitive strategy: an analysis of its impact on 
medical resources." Journal of Health Economics, 16:3 (June, 1997) 261-286.

Hillman, Alan L. and J. Sanford Schwartz, "The adoption and diffusion of CT and MRI in the United States." Medical Care, 23:11 (November, 1985) 1283-1294.

Hillman, Alan L. and J. Sanford Schwartz, "The diffusion of MRI: Patterns of siting and ownership in an era of changing incentives." American Journal of Roentgenology, 146 (May, 1986) 963-969.

Interstudy, Competitive Edge. 1997, Excelsior, MN: Interstudy.

Lee, Robert H. and Donald M. Waldman, "The diffusion of innovations in hospitals: Some econometric considerations." Journal of Health Economics, 4 (1985) 373-380.

Makuc, DM, B Haglund, DD Ingram, JX Kleinman, and JJ Feldman, Health Care Service Areas for the United States, Vital and Health Statistics, Series 2, no 112, PHS 92-1386, National Center for Health Statistics: Washington DC, November, 1991.

Mansfield, E. Industrial Research and Technological Innovation: An econometric analysis. New York: Norton and Company, 1968.

McLaughlin, Catherine G., "HMO growth and hospital expenses and use: A simultaneousequation approach." HSR: Health Services Research, 22:2 (June, 1987) 183-205.

McLaughlin, Catherine G., "The effect of HMOs on overall hospital expenses: Is anything left after correcting for simultaneity and selectivity?" HSR: Health Services Research, 23:3 (August, 1988) 421-441.

Meyer, Bruce D., "Unemployment Insurance and Unemployment Spells," Econometrica 58:4 (July 1990) 757-782.

Miller, Robert H. and Harold S. Luft, "Does managed care lead to better or worse quality of care?" Health Affairs, $16: 5$ (September/October, 1997) 7-25.

Newhouse, Joseph P., "Medical care costs: How much welfare loss?" Journal of Economic Perspectives, 6:3 (1992) 3-21.

Noether, Monica, "Competition among hospitals." Journal of Health Economics, 7:3 (September, 1988) 259-284.

Prentice, Ross, and L. Gloeckler, "Regression Analysis of Grouped Survival Data with Application to Breast Cancer Data" Biometrics 34 (1978) 57-67.

Reinganum, Jennifer F., "The timing of innovation: research, development, and diffusion" in R. Schmalensee and R.D. Willig eds, Handbook of Industrial Organization, volume 1, 
Amsterdam: North Holland, 1989, p849-908.

Robinson, James C., "HMO market penetration and hospital cost inflation in California." Journal of the American Medical Association, 266:19 (November 20, 1991) 2719-2723.

Robinson, James C., "Decline in hospital utilization and cost inflation under managed care in California." Journal of the American Medical Association, 276:13 (October 2, 1996) 1060-1064.

Romeo, Anthony A., Judith L. Wagner, and Robert H. Lee, "Prospective reimbursement and the diffusion of new technologies in hospitals." Journal of Health Economics, 3 (1984) 1-24.

Rose, Nancy L., and Paul L. Joskow, "The diffusion of new technologies: evidence from the electric utility industry" Rand Journal of Economics 21:3 (Autumn 1990) 354-373.

Russell, Louise B., "The diffusion of hospital technologies: some econometric evidence." Journal of Human Resources 12:4 (1977) 482-502

Salkever, David S. and Thomas W. Bice, "The impact of certificate-of-need controls on hospital investment." Milbank Memorial Fund Quarterly, 53 (1976) 185-214.

Steinberg, Earl P., and Robert G. Evens, "Economics (chapter 14)" in Magnetic Resonance Imaging, ed. D.D. Stark and W.G. Bradley, 1988, St. Louis, MO, CV Moseby.

Teplensky, Jill D., "Organizational adoption and a capital based technology under conditions of changing uncertainty: A competitive analysis," Case Western Reserve University, 1993.

Teplensky, Jill D., "Organizational adoption of technological innovations: Binary decision behavior or continuum of options," Case Western Reserve University, 1994.

Teplensky, Jill D., Mark V. Pauly, John R. Kimberly, Alan L. Hillman, and J. Sanford Schwartz, "Hospital adoption of medical technology: An empirical test of alternative models." HSR: Health Services Research, August, 1995.

Vanden Brink, John et al, "The Impact of Managed Care on Medical Technology Utilization" Technology Marketing Group, Des Plaines, IL July 1995.

Vogt, William B., "Detecting Strategic Behavior in Technology Adoption: the example of magnetic resonance imaging." manuscript, Carnegie Mellon University, March 1997.

Weisbrod, Burton, "The health care quadrilemma: An essay on technological change, insurance, quality of care, and cost containment." Journal of Economic Literature, 29 (June, 1991) 523-552.

Welch, W. Pete, HMO market share and its effect on local Medicare costs, in HMOs and the 
Elderly, Harold S. Luft, Editor. 1994, Health Administration Press: Ann Arbor, MI. p. 231-249.

Wickizer, Thomas M. and Paul J. Feldstein, "The impact of HMO competition on private health insurance premiums, 1985-1992." Inquiry, 32:3 (Fall, 1995) 241-251. 
Table 1 : Summary of Hospital MRI Adoption Data

\begin{tabular}{|c|c|c|c|c|c|c|}
\hline $\begin{array}{l}\text { Survey } \\
\text { Year }\end{array}$ & $\begin{array}{l}\text { Hospitals } \\
\text { "At Risk" }\end{array}$ & $\begin{array}{c}\text { Yearly } \\
\text { Adoptions }\end{array}$ & $\begin{array}{l}\text { Cumulative } \\
\text { Adoptions }\end{array}$ & Censored & $\begin{array}{l}\text { Kaplan- } \\
\text { Meier } \\
\text { Survivor } \\
\text { Function } \\
\text { S(t) }\end{array}$ & $\begin{array}{c}\text { Cumulative } \\
\text { Adoption } \\
\text { Probability } \\
1-\mathrm{S}(\mathrm{t}) \\
\end{array}$ \\
\hline 1983 & 5344 & 104 & 104 & 28 & 0.981 & 0.019 \\
\hline 1984 & 5212 & 38 & 142 & 71 & 0.973 & 0.027 \\
\hline 1985 & 5103 & 102 & 244 & 94 & 0.954 & 0.046 \\
\hline 1986 & 4907 & 112 & 356 & 103 & 0.932 & 0.068 \\
\hline 1987 & 4692 & 126 & 482 & 114 & 0.907 & 0.093 \\
\hline 1988 & 4452 & 145 & 627 & 85 & 0.878 & 0.122 \\
\hline 1989 & 4222 & 89 & 716 & 118 & 0.859 & 0.141 \\
\hline 1990 & 4015 & 98 & 814 & 94 & 0.838 & 0.162 \\
\hline 1991 & 3823 & 100 & 914 & 131 & 0.816 & 0.184 \\
\hline 1992 & 3592 & 105 & 1019 & 52 & 0.792 & 0.208 \\
\hline 1993 & 3435 & 157 & 1176 & 3278 & 0.756 & 0.244 \\
\hline
\end{tabular}

Note: The baseline sample is 5,344 hospitals in HCSAs with population of more than 25,000 observed in 1983. The number of hospitals at risk is the number that had not previously adopted or been censored. The number of adoptions is the number of hospitals observed to adopt in the interval between the year indicated and the prior year. Censored observations are those not observed to adopt in the indicated year, and not observed in subsequent years. 
Table 2: MRI Availability and Use Measures, 1993 and 1995

\begin{tabular}{|c|c|c|c|c|c|c|c|}
\hline Year & $\begin{array}{c}\text { MRI } \\
\text { Sites } \\
(1) \\
\end{array}$ & $\begin{array}{c}\text { Magnets } \\
\text { (2) }\end{array}$ & $\begin{array}{l}\text { Magnets } \\
\text { in } \\
\text { Hospitals } \\
\text { (3) } \\
\end{array}$ & $\begin{array}{c}\text { Magnets } \\
\text { outside } \\
\text { Hospitals } \\
(4) \\
\end{array}$ & $\begin{array}{c}\text { Total } \\
\text { Procedures } \\
(5) \\
\end{array}$ & $\begin{array}{c}\text { Hospital } \\
\text { Procedures } \\
(6) \\
\end{array}$ & $\begin{array}{c}\text { Non-Hospital } \\
\text { Procedures } \\
(7) \\
\end{array}$ \\
\hline \multicolumn{8}{|l|}{ Totals } \\
\hline 1993 & 2,166 & 2,413 & 1,291 & 1,122 & $7,721,044$ & $4,147,081$ & $3,573,963$ \\
\hline 1995 & 2,484 & 2,787 & 1,545 & 1,242 & $8,190,736$ & $4,711,704$ & $3,479,032$ \\
\hline$\Delta$ 1993-1995 & 318 & 374 & 254 & 120 & 469,692 & 564,623 & $-94,931$ \\
\hline$\%$ change & $15 \%$ & $15 \%$ & $20 \%$ & $11 \%$ & $6 \%$ & $14 \%$ & $-3 \%$ \\
\hline \multicolumn{8}{|c|}{ Per 100,000 Population } \\
\hline 1993 & 0.85 & 0.95 & 0.51 & 0.44 & 3,033 & 1,629 & 1,404 \\
\hline 1995 & 0.98 & 1.09 & 0.61 & 0.49 & 3,712 & 1,850 & 1,366 \\
\hline$\Delta$ 1993-1995 & 0.12 & 0.15 & 0.10 & 0.05 & 184 & 222 & -37 \\
\hline$\%$ change & $15 \%$ & $15 \%$ & $20 \%$ & $11 \%$ & $6 \%$ & $14 \%$ & $-3 \%$ \\
\hline
\end{tabular}

Note: These data pertain to all HCSAs with 1993 population >25,000. 
Table 3: Estimates from Hospital MRI Adoption Hazard Models, 1983-1993

\begin{tabular}{|c|c|c|c|c|c|}
\hline & \multicolumn{4}{|c|}{ Hazard Model Results } & \multirow{2}{*}{$\begin{array}{c}\text { Variable } \\
\text { Means } \\
(5)\end{array}$} \\
\hline & $(1)$ & $(2)$ & (3) & $(4)$ & \\
\hline HMO market share $1-5 \%$ & $\begin{array}{l}-0.009 \\
(0.123) \\
{[0.991]}\end{array}$ & $\begin{array}{c}-0.083 \\
(0.136) \\
{[0.920]}\end{array}$ & $\begin{array}{c}-0.006 \\
(0.123) \\
{[0.994]}\end{array}$ & $\begin{array}{l}-0.008 \\
(0.123) \\
{[0.992]}\end{array}$ & $\begin{array}{c}0.178 \\
(0.383)\end{array}$ \\
\hline HMO market share $5-15 \%$ & $\begin{array}{l}-0.264 \\
(0.126) \\
{[0.768]}\end{array}$ & $\begin{array}{c}-0.380 \\
(0.139) \\
{[0.684]}\end{array}$ & $\begin{array}{c}-0.250 \\
(0.126) \\
{[0.778]}\end{array}$ & $\begin{array}{l}-0.260 \\
(0.126) \\
{[0.771]}\end{array}$ & $\begin{array}{c}0.331 \\
(0.470)\end{array}$ \\
\hline HMO market share $15-25 \%$ & $\begin{array}{l}-0.250 \\
(0.146) \\
{[0.779]}\end{array}$ & $\begin{array}{l}-0.495 \\
(0.183) \\
{[0.610]}\end{array}$ & $\begin{array}{c}-0.260 \\
(0.147) \\
{[0.771]}\end{array}$ & $\begin{array}{l}-0.319 \\
(0.150) \\
{[0.727]}\end{array}$ & $\begin{array}{c}0.162 \\
(0.369)\end{array}$ \\
\hline HMO market share $\geq 25 \%$ & $\begin{array}{l}-0.333 \\
(0.160) \\
{[0.717]}\end{array}$ & $\begin{array}{c}-0.524 \\
(0.226) \\
{[0.592]}\end{array}$ & $\begin{array}{c}-0.362 \\
(0.159) \\
{[0.696]}\end{array}$ & $\begin{array}{l}-0.348 \\
(0.161) \\
{[0.706]}\end{array}$ & $\begin{array}{c}0.144 \\
(0.352)\end{array}$ \\
\hline Hospital had CT in 1983 & - & - & $\begin{array}{c}0.961 \\
(0.086) \\
{[2.614]}\end{array}$ & - & $\begin{array}{c}0.387 \\
(0.487)\end{array}$ \\
\hline Hospital had ultrasound in 1983 & - & - & $\begin{array}{c}0.455 \\
(0.132) \\
{[1.576]}\end{array}$ & - & $\begin{array}{c}0.756 \\
(0.430)\end{array}$ \\
\hline $\begin{array}{l}\text { Non-hospital MRI machines per } \\
\text { population in } 1993\end{array}$ & - & - & - & $\begin{array}{l}-0.407 \\
(0.112) \\
{[0.666]}\end{array}$ & $\begin{array}{c}0.360 \\
(0.363)\end{array}$ \\
\hline$\%$ pop over age 65 & $\begin{array}{l}-0.032 \\
(0.016)\end{array}$ & $\begin{array}{l}-0.054 \\
(0.020)\end{array}$ & $\begin{array}{l}-0.044 \\
(0.016)\end{array}$ & $\begin{array}{l}-0.029 \\
(0.016)\end{array}$ & $\begin{array}{l}13.307 \\
(2.980)\end{array}$ \\
\hline$\%$ pop high school graduate & $\begin{array}{c}0.002 \\
(0.007)\end{array}$ & $\begin{array}{c}0.018 \\
(0.012)\end{array}$ & $\begin{array}{c}0.000 \\
(0.008)\end{array}$ & $\begin{array}{c}0.001 \\
(0.008)\end{array}$ & $\begin{array}{l}73.829 \\
(7.468)\end{array}$ \\
\hline$\%$ pop college graduate & $\begin{array}{c}0.006 \\
(0.014)\end{array}$ & $\begin{array}{l}-0.017 \\
(0.017)\end{array}$ & $\begin{array}{c}0.008 \\
(0.014)\end{array}$ & $\begin{array}{c}0.004 \\
(0.014)\end{array}$ & $\begin{array}{l}18.254 \\
(6.166)\end{array}$ \\
\hline Per capita income $/ 1000$ & $\begin{array}{l}-0.035 \\
(0.019)\end{array}$ & $\begin{array}{c}0.018 \\
(0.022)\end{array}$ & $\begin{array}{l}-0.037 \\
(0.019)\end{array}$ & $\begin{array}{l}-0.030 \\
(0.019)\end{array}$ & $\begin{array}{l}19.323 \\
(4.074)\end{array}$ \\
\hline$\%$ pop urban & $\begin{array}{l}-0.061 \\
(0.105)\end{array}$ & $\begin{array}{l}-0.025 \\
(0.120)\end{array}$ & $\begin{array}{l}-0.098 \\
(0.105)\end{array}$ & $\begin{array}{l}-0.056 \\
(0.106)\end{array}$ & $\begin{array}{c}6.616 \\
(2.318)\end{array}$ \\
\hline$(\% \text { pop urban })^{2}$ & $\begin{array}{c}0.014 \\
(0.008) \\
\end{array}$ & $\begin{array}{c}0.003 \\
(0.010) \\
\end{array}$ & $\begin{array}{r}0.017 \\
(0.008) \\
\end{array}$ & $\begin{array}{c}0.015 \\
(0.009) \\
\end{array}$ & $\begin{array}{c}49.147 \\
(29.402) \\
\end{array}$ \\
\hline
\end{tabular}


Table 3, continued

\begin{tabular}{|c|c|c|c|c|c|}
\hline & $(1)$ & $(2)$ & (3) & $(4)$ & $(5)$ \\
\hline Area population $/ 1,000,000$ & $\begin{array}{l}-0.084 \\
(0.068)\end{array}$ & $\begin{array}{l}-0.011 \\
(0.081)\end{array}$ & $\begin{array}{l}-0.078 \\
(0.066)\end{array}$ & $\begin{array}{l}-0.090 \\
(0.069)\end{array}$ & $\begin{array}{c}1.272 \\
(2.253)\end{array}$ \\
\hline$(\text { Area population) })^{2}$ & $\begin{array}{c}0.007 \\
(0.005)\end{array}$ & $\begin{array}{l}-0.001 \\
(0.006)\end{array}$ & $\begin{array}{c}0.006 \\
(0.005)\end{array}$ & $\begin{array}{c}0.007 \\
(0.005)\end{array}$ & $\begin{array}{c}6.693 \\
(24.013)\end{array}$ \\
\hline Pop per square mile /1000 & $\begin{array}{l}-0.245 \\
(0.075)\end{array}$ & $\begin{array}{c}0.003 \\
(0.051)\end{array}$ & $\begin{array}{c}-0.223 \\
(0.074)\end{array}$ & $\begin{array}{c}-0.241 \\
(0.075)\end{array}$ & $\begin{array}{c}0.714 \\
(3.147)\end{array}$ \\
\hline$(\text { Pop per square mile })^{2}$ & $\begin{array}{c}0.005 \\
(0.002)\end{array}$ & $\begin{array}{c}0.000 \\
(0.001)\end{array}$ & $\begin{array}{c}0.005 \\
(0.002)\end{array}$ & $\begin{array}{c}0.005 \\
(0.002)\end{array}$ & $\begin{array}{c}10.410 \\
(111.594)\end{array}$ \\
\hline Area hospitals / 1000 pop & $\begin{array}{l}-7.084 \\
(2.903)\end{array}$ & $\begin{array}{l}-11.823 \\
(3.572)\end{array}$ & $\begin{array}{l}-1.555 \\
(2.821)\end{array}$ & $\begin{array}{l}-7.386 \\
(2.913)\end{array}$ & $\begin{array}{c}0.029 \\
(0.023)\end{array}$ \\
\hline Area generalists $/ 1000$ pop & $\begin{array}{l}-0.768 \\
(0.528)\end{array}$ & $\begin{array}{l}-0.002 \\
(0.609)\end{array}$ & $\begin{array}{l}-0.484 \\
(0.540)\end{array}$ & $\begin{array}{l}-0.844 \\
(0.534)\end{array}$ & $\begin{array}{c}0.514 \\
(0.137)\end{array}$ \\
\hline Area specialists /1000 pop & $\begin{array}{c}1.002 \\
(0.278)\end{array}$ & $\begin{array}{c}0.423 \\
(0.295)\end{array}$ & $\begin{array}{c}0.800 \\
(0.282)\end{array}$ & $\begin{array}{c}1.157 \\
(0.282)\end{array}$ & $\begin{array}{c}0.863 \\
(0.401)\end{array}$ \\
\hline Area radiologists /1000 pop & $\begin{array}{l}-5.598 \\
(2.556)\end{array}$ & $\begin{array}{l}-1.991 \\
(2.597)\end{array}$ & $\begin{array}{l}-4.344 \\
(2.552)\end{array}$ & $\begin{array}{l}-6.105 \\
(2.525)\end{array}$ & $\begin{array}{c}0.070 \\
(0.030)\end{array}$ \\
\hline Medicare AAPCC /100 & $\begin{array}{c}0.007 \\
(0.075)\end{array}$ & $\begin{array}{l}-0.059 \\
(0.104)\end{array}$ & $\begin{array}{l}-0.061 \\
(0.075)\end{array}$ & $\begin{array}{c}0.033 \\
(0.075)\end{array}$ & $\begin{array}{c}3.448 \\
(0.739)\end{array}$ \\
\hline Medical school affiliation & $\begin{array}{c}0.380 \\
(0.093)\end{array}$ & $\begin{array}{c}0.476 \\
(0.097)\end{array}$ & $\begin{array}{c}0.136 \\
(0.088)\end{array}$ & $\begin{array}{c}0.391 \\
(0.093)\end{array}$ & $\begin{array}{c}0.163 \\
(0.370)\end{array}$ \\
\hline COTH member & $\begin{array}{c}0.128 \\
(0.119)\end{array}$ & $\begin{array}{c}0.178 \\
(0.122)\end{array}$ & $\begin{array}{c}0.288 \\
(0.112)\end{array}$ & $\begin{array}{c}0.109 \\
(0.119)\end{array}$ & $\begin{array}{c}0.060 \\
(0.237)\end{array}$ \\
\hline Children's hospital & $\begin{array}{c}0.746 \\
(0.233)\end{array}$ & $\begin{array}{c}0.646 \\
(0.238)\end{array}$ & $\begin{array}{c}0.793 \\
(0.235)\end{array}$ & $\begin{array}{c}0.711 \\
(0.234)\end{array}$ & $\begin{array}{c}0.008 \\
(0.088)\end{array}$ \\
\hline Average bed size /100 & $\begin{array}{c}0.342 \\
(0.019)\end{array}$ & $\begin{array}{c}0.335 \\
(0.020)\end{array}$ & $\begin{array}{c}0.285 \\
(0.019)\end{array}$ & $\begin{array}{c}0.343 \\
(0.019)\end{array}$ & $\begin{array}{c}1.754 \\
(1.708)\end{array}$ \\
\hline State dummies & No & Yes & No & No & --- \\
\hline $\begin{array}{l}\mathrm{N} \\
\text { Log-likelihood }\end{array}$ & $\begin{array}{c}5344 \\
-4820.51\end{array}$ & $\begin{array}{c}5344 \\
-4732.84\end{array}$ & $\begin{array}{c}5344 \\
-4711.97\end{array}$ & $\begin{array}{c}5344 \\
-4812.95\end{array}$ & $\begin{array}{c}5344 \\
-\end{array}$ \\
\hline
\end{tabular}

Note: Robust standard errors in parentheses. Hazard ratios in brackets. All equations include 11 baseline hazard parameters. COTH is council of teaching hospitals. 
Table 4: OLS Estimates From Cross-Sectional Models of Hospitals With MRI Per Population, 1993, 1994, 1996, 1998

\begin{tabular}{|c|c|c|c|c|}
\hline & $\begin{array}{c}1993 \\
(1)\end{array}$ & $\begin{array}{c}1994 \\
(2) \\
\end{array}$ & $\begin{array}{c}1996 \\
(3) \\
\end{array}$ & $\begin{array}{c}1998 \\
(4) \\
\end{array}$ \\
\hline $\begin{array}{l}\text { National Avg Hospitals } \\
\text { with MRI/ 100,000 pop. }\end{array}$ & 0.376 & 0.670 & 0.738 & 0.771 \\
\hline HMO market share $1-5 \%$ & $\begin{array}{c}0.027 \\
(0.062)\end{array}$ & $\begin{array}{l}-0.151 \\
(0.101)\end{array}$ & $\begin{array}{l}-0.156 \\
(0.123)\end{array}$ & $\begin{array}{l}-0.223 \\
(0.123)\end{array}$ \\
\hline HMO market share $5-15 \%$ & $\begin{array}{l}-0.013 \\
(0.056)\end{array}$ & $\begin{array}{l}-0.203 \\
(0.103)\end{array}$ & $\begin{array}{l}-0.237 \\
(0.118)\end{array}$ & $\begin{array}{l}-0.329 \\
(0.122)\end{array}$ \\
\hline HMO market share $15-25 \%$ & $\begin{array}{l}-0.112 \\
(0.066)\end{array}$ & $\begin{array}{l}-0.286 \\
(0.125)\end{array}$ & $\begin{array}{l}-0.297 \\
(0.148)\end{array}$ & $\begin{array}{l}-0.417 \\
(0.158)\end{array}$ \\
\hline HMO market share $\geq 25 \%$ & $\begin{array}{l}-0.149 \\
(0.087)\end{array}$ & $\begin{array}{l}-0.353 \\
(0.133)\end{array}$ & $\begin{array}{l}-0.410 \\
(0.163)\end{array}$ & $\begin{array}{l}-0.526 \\
(0.185)\end{array}$ \\
\hline $\begin{array}{l}\mathrm{N} \\
\mathrm{R}^{2}\end{array}$ & $\begin{array}{c}707 \\
0.087\end{array}$ & $\begin{array}{c}707 \\
0.070\end{array}$ & $\begin{array}{c}707 \\
0.139\end{array}$ & $\begin{array}{c}707 \\
0.214\end{array}$ \\
\hline Predicted levels & & & & \\
\hline $\begin{array}{l}\text { Market share }<1 \% \\
\text { Market share } 1-5 \% \\
\text { Market share } 5-15 \% \\
\text { Market share } 15-25 \% \\
\text { Market share } \geq 25\end{array}$ & $\begin{array}{l}0.391 \\
0.418 \\
0.378 \\
0.279 \\
0.242\end{array}$ & $\begin{array}{l}0.815 \\
0.664 \\
0.612 \\
0.529 \\
0.462\end{array}$ & $\begin{array}{l}0.899 \\
0.743 \\
0.662 \\
0.602 \\
0.489\end{array}$ & $\begin{array}{l}0.995 \\
0.772 \\
0.665 \\
0.578 \\
0.469\end{array}$ \\
\hline
\end{tabular}

Note: Robust standard errors in parentheses. Models also control for the area covariates shown in Table 3 and average size of area hospitals. Predicted levels are evaluated around the national means. 
Table 5: OLS Estimates From Models of Magnets Per Population, 1993 and 1995

\begin{tabular}{|c|c|c|c|c|c|c|}
\hline & \multicolumn{2}{|c|}{$\begin{array}{l}\text { Total Magnets } \\
\text { per } 100,000 \text { pop. }\end{array}$} & \multicolumn{2}{|c|}{$\begin{array}{l}\text { Hospital Magnets } \\
\text { per } 100,000 \text { pop }\end{array}$} & \multicolumn{2}{|c|}{$\begin{array}{l}\text { Non-Hospital Magnets } \\
\text { per } 100,000 \text { pop }\end{array}$} \\
\hline & $\begin{array}{c}1993 \\
(1)\end{array}$ & $\begin{array}{l}1995 \\
(2)\end{array}$ & $\begin{array}{c}1993 \\
(3)\end{array}$ & $\begin{array}{l}1995 \\
(4)\end{array}$ & $\begin{array}{c}1993 \\
(5) \\
\end{array}$ & $\begin{array}{c}1995 \\
(6)\end{array}$ \\
\hline Market share $1-5 \%$ & $\begin{array}{l}-0.077 \\
(0.062)\end{array}$ & $\begin{array}{l}-0.134 \\
(0.072)\end{array}$ & $\begin{array}{l}-0.094 \\
(0.056)\end{array}$ & $\begin{array}{l}-0.138 \\
(0.070)\end{array}$ & $\begin{array}{c}0.016 \\
(0.034)\end{array}$ & $\begin{array}{c}0.004 \\
(0.035)\end{array}$ \\
\hline Market share $5-15 \%$ & $\begin{array}{l}-0.074 \\
(0.066)\end{array}$ & $\begin{array}{l}-0.150 \\
(0.076)\end{array}$ & $\begin{array}{l}-0.091 \\
(0.058)\end{array}$ & $\begin{array}{l}-0.148 \\
(0.072)\end{array}$ & $\begin{array}{c}0.017 \\
(0.038)\end{array}$ & $\begin{array}{l}-0.002 \\
(0.042)\end{array}$ \\
\hline Market share $15-25 \%$ & $\begin{array}{l}-0.182 \\
(0.086)\end{array}$ & $\begin{array}{l}-0.239 \\
(0.097)\end{array}$ & $\begin{array}{l}-0.143 \\
(0.070)\end{array}$ & $\begin{array}{l}-0.231 \\
(0.084)\end{array}$ & $\begin{array}{l}-0.039 \\
(0.061)\end{array}$ & $\begin{array}{l}-0.008 \\
(0.067)\end{array}$ \\
\hline Market share $\geq 25 \%$ & $\begin{array}{l}-0.144 \\
(0.087)\end{array}$ & $\begin{array}{l}-0.282 \\
(0.105)\end{array}$ & $\begin{array}{l}-0.132 \\
(0.081)\end{array}$ & $\begin{array}{l}-0.262 \\
(0.095)\end{array}$ & $\begin{array}{l}-0.012 \\
(0.059)\end{array}$ & $\begin{array}{l}-0.020 \\
(0.069)\end{array}$ \\
\hline$\%$ pop over age 65 & $\begin{array}{l}-0.011 \\
(0.010)\end{array}$ & $\begin{array}{l}-0.004 \\
(0.011)\end{array}$ & $\begin{array}{l}-0.012 \\
(0.008)\end{array}$ & $\begin{array}{l}-0.014 \\
(0.011)\end{array}$ & $\begin{array}{c}0.001 \\
(0.005)\end{array}$ & $\begin{array}{c}0.010 \\
(0.006)\end{array}$ \\
\hline$\%$ pop high school graduate & $\begin{array}{l}-0.002 \\
(0.004)\end{array}$ & $\begin{array}{l}-0.002 \\
(0.004)\end{array}$ & $\begin{array}{c}0.001 \\
(0.003)\end{array}$ & $\begin{array}{c}0.002 \\
(0.004)\end{array}$ & $\begin{array}{l}-0.002 \\
(0.002)\end{array}$ & $\begin{array}{l}-0.004 \\
(0.003)\end{array}$ \\
\hline$\%$ pop college graduate & $\begin{array}{l}-0.010 \\
(0.008)\end{array}$ & $\begin{array}{l}-0.004 \\
(0.010)\end{array}$ & $\begin{array}{c}0.001 \\
(0.007)\end{array}$ & $\begin{array}{l}-0.001 \\
(0.009)\end{array}$ & $\begin{array}{l}-0.011 \\
(0.004)\end{array}$ & $\begin{array}{l}-0.003 \\
(0.004)\end{array}$ \\
\hline Per capita income /1000 & $\begin{array}{l}-0.011 \\
(0.013)\end{array}$ & $\begin{array}{l}-0.005 \\
(0.015)\end{array}$ & $\begin{array}{l}-0.025 \\
(0.010)\end{array}$ & $\begin{array}{l}-0.023 \\
(0.013)\end{array}$ & $\begin{array}{c}0.014 \\
(0.009)\end{array}$ & $\begin{array}{c}0.017 \\
(0.009)\end{array}$ \\
\hline$\%$ pop urban & $\begin{array}{c}0.104 \\
(0.044)\end{array}$ & $\begin{array}{c}0.149 \\
(0.048)\end{array}$ & $\begin{array}{c}0.116 \\
(0.037)\end{array}$ & $\begin{array}{c}0.134 \\
(0.045)\end{array}$ & $\begin{array}{c}-0.012 \\
(0.024)\end{array}$ & $\begin{array}{c}0.015 \\
(0.025)\end{array}$ \\
\hline$(\% \text { pop urban })^{2}$ & $\begin{array}{l}-0.005 \\
(0.004)\end{array}$ & $\begin{array}{c}-0.009 \\
(0.005)\end{array}$ & $\begin{array}{l}-0.010 \\
(0.004)\end{array}$ & $\begin{array}{c}-0.012 \\
(0.004)\end{array}$ & $\begin{array}{c}0.005 \\
(0.003)\end{array}$ & $\begin{array}{c}0.002 \\
(0.003)\end{array}$ \\
\hline Area population $/ 1,000,000$ & $\begin{array}{l}-0.032 \\
(0.069)\end{array}$ & $\begin{array}{c}-0.026 \\
(0.076)\end{array}$ & $\begin{array}{l}-0.013 \\
(0.054)\end{array}$ & $\begin{array}{l}-0.042 \\
(0.060)\end{array}$ & $\begin{array}{l}-0.019 \\
(0.059)\end{array}$ & $\begin{array}{c}0.015 \\
(0.061)\end{array}$ \\
\hline$(\text { Area population })^{2}$ & $\begin{array}{c}0.001 \\
(0.005)\end{array}$ & $\begin{array}{c}0.000 \\
(0.006)\end{array}$ & $\begin{array}{c}0.002 \\
(0.004)\end{array}$ & $\begin{array}{c}0.004 \\
(0.005)\end{array}$ & $\begin{array}{c}-0.001 \\
(0.005)\end{array}$ & $\begin{array}{c}-0.004 \\
(0.005)\end{array}$ \\
\hline Pop per square mile $/ 1000$ & $\begin{array}{l}-0.041 \\
(0.033)\end{array}$ & $\begin{array}{l}-0.064 \\
(0.047)\end{array}$ & $\begin{array}{l}-0.063 \\
(0.029)\end{array}$ & $\begin{array}{l}-0.070 \\
(0.035)\end{array}$ & $\begin{array}{c}0.021 \\
(0.023)\end{array}$ & $\begin{array}{c}0.006 \\
(0.027)\end{array}$ \\
\hline
\end{tabular}

Continued 
Table 5, continued

\begin{tabular}{|c|c|c|c|c|c|c|}
\hline & \multicolumn{2}{|c|}{$\begin{array}{l}\text { Total Magnets } \\
\text { per } 100,000 \text { pop. }\end{array}$} & \multicolumn{2}{|c|}{$\begin{array}{l}\text { Hospital Magnets } \\
\text { per } 100,000 \text { pop }\end{array}$} & \multicolumn{2}{|c|}{$\begin{array}{c}\text { Non-Hospital Magnets } \\
\text { per } 100,000 \text { pop }\end{array}$} \\
\hline & $\begin{array}{l}1993 \\
(1)\end{array}$ & $\begin{array}{l}1995 \\
(2)\end{array}$ & $\begin{array}{c}1993 \\
(3)\end{array}$ & $\begin{array}{l}1995 \\
(4)\end{array}$ & $\begin{array}{c}1993 \\
(5)\end{array}$ & $\begin{array}{c}1995 \\
(6)\end{array}$ \\
\hline$(\text { Pop per square mile })^{2}$ & $\begin{array}{c}0.000 \\
(0.001)\end{array}$ & $\begin{array}{c}0.001 \\
(0.001)\end{array}$ & $\begin{array}{c}0.001 \\
(0.001)\end{array}$ & $\begin{array}{c}0.002 \\
(0.001)\end{array}$ & $\begin{array}{l}-0.001 \\
(0.001)\end{array}$ & $\begin{array}{l}-0.001 \\
(0.001)\end{array}$ \\
\hline Hospitals /1000 pop & $\begin{array}{l}1.066 \\
(1.485)\end{array}$ & $\begin{array}{c}4.573 \\
(1.999)\end{array}$ & $\begin{array}{c}1.020 \\
(1.273)\end{array}$ & $\begin{array}{c}4.957 \\
(1.951)\end{array}$ & $\begin{array}{c}0.046 \\
(0.689)\end{array}$ & $\begin{array}{l}-0.384 \\
(0.744)\end{array}$ \\
\hline Generalists /1000 pop & $\begin{array}{l}-0.687 \\
(0.294)\end{array}$ & $\begin{array}{l}-0.324 \\
(0.332)\end{array}$ & $\begin{array}{l}-0.496 \\
(0.270)\end{array}$ & $\begin{array}{l}-0.135 \\
(0.312)\end{array}$ & $\begin{array}{l}-0.191 \\
(0.143)\end{array}$ & $\begin{array}{l}-0.189 \\
(0.167)\end{array}$ \\
\hline Specialists /1000 pop & $\begin{array}{c}1.112 \\
(0.160)\end{array}$ & $\begin{array}{c}1.029 \\
(0.195)\end{array}$ & $\begin{array}{c}0.638 \\
(0.155)\end{array}$ & $\begin{array}{c}0.689 \\
(0.188)\end{array}$ & $\begin{array}{c}0.474 \\
(0.100)\end{array}$ & $\begin{array}{c}0.341 \\
(0.109)\end{array}$ \\
\hline Radiologists /1000 pop & $\begin{array}{l}-0.678 \\
(1.212)\end{array}$ & $\begin{array}{l}-1.264 \\
(1.705)\end{array}$ & $\begin{array}{l}-0.193 \\
(1.093)\end{array}$ & $\begin{array}{l}-0.579 \\
(1.671)\end{array}$ & $\begin{array}{l}-0.485 \\
(0.657)\end{array}$ & $\begin{array}{l}-0.685 \\
(0.685)\end{array}$ \\
\hline Medicare AAPCC /100 & $\begin{array}{c}0.058 \\
(0.052)\end{array}$ & $\begin{array}{c}0.197 \\
(0.065)\end{array}$ & $\begin{array}{c}0.005 \\
(0.046)\end{array}$ & $\begin{array}{c}0.127 \\
(0.063)\end{array}$ & $\begin{array}{c}0.053 \\
(0.028)\end{array}$ & $\begin{array}{c}0.070 \\
(0.031)\end{array}$ \\
\hline Avg beds in area hospitals & $\begin{array}{c}0.074 \\
(0.038)\end{array}$ & $\begin{array}{c}0.092 \\
(0.047)\end{array}$ & $\begin{array}{c}0.082 \\
(0.034)\end{array}$ & $\begin{array}{c}0.079 \\
(0.044)\end{array}$ & $\begin{array}{l}-0.008 \\
(0.027)\end{array}$ & $\begin{array}{c}0.013 \\
(0.030)\end{array}$ \\
\hline Constant & $\begin{array}{c}0.268 \\
(0.309)\end{array}$ & $\begin{array}{l}-0.558 \\
(0.402)\end{array}$ & $\begin{array}{c}0.401 \\
(0.257)\end{array}$ & $\begin{array}{l}-0.193 \\
(0.388)\end{array}$ & $\begin{array}{l}-0.133 \\
(0.162)\end{array}$ & $\begin{array}{l}-0.365 \\
(0.185)\end{array}$ \\
\hline $\begin{array}{l}\mathrm{N} \\
\mathrm{R}^{2}\end{array}$ & $\begin{array}{c}707 \\
0.309\end{array}$ & $\begin{array}{c}707 \\
0.250\end{array}$ & $\begin{array}{c}707 \\
0.145\end{array}$ & $\begin{array}{c}707 \\
0.119\end{array}$ & $\begin{array}{c}707 \\
0.283\end{array}$ & $\begin{array}{c}707 \\
0.275\end{array}$ \\
\hline \multicolumn{7}{|l|}{ Predicted Values } \\
\hline $\begin{array}{l}\text { Market share }<1 \% \\
\text { Market share } 1-5 \% \\
\text { Market share } 5-15 \% \\
\text { Market share } 15-25 \% \\
\text { Markets share } \geq 25\end{array}$ & $\begin{array}{l}0.718 \\
0.641 \\
0.644 \\
0.537 \\
0.574\end{array}$ & $\begin{array}{l}0.928 \\
0.794 \\
0.778 \\
0.689 \\
0.646\end{array}$ & $\begin{array}{l}0.492 \\
0.398 \\
0.401 \\
0.349 \\
0.360\end{array}$ & $\begin{array}{l}0.676 \\
0.539 \\
0.528 \\
0.446 \\
0.415\end{array}$ & $\begin{array}{l}0.226 \\
0.242 \\
0.243 \\
0.187 \\
0.214\end{array}$ & $\begin{array}{l}0.252 \\
0.256 \\
0.250 \\
0.243 \\
0.231\end{array}$ \\
\hline
\end{tabular}

Note: Robust standard errors in parentheses. The models also control for urbanization, demographics, and area health system characteristics. Predicted values are computed holding other covariates in the models at their sample means, and reflect unweighted means across areas. 
Table 6: Estimates From OLS Regression Models of the Number of MRI Procedures per Population, 1993 and 1995

\begin{tabular}{|c|c|c|c|c|c|c|}
\hline & \multicolumn{2}{|c|}{$\begin{array}{l}\text { Total Procedures } \\
\text { per } 100,000 \text { pop. }\end{array}$} & \multicolumn{2}{|c|}{$\begin{array}{l}\text { Hospital Procedures } \\
\text { per } 100,000 \text { pop }\end{array}$} & \multicolumn{2}{|c|}{$\begin{array}{c}\text { Non-Hosp. Procedures } \\
\text { per } 100,000 \text { pop }\end{array}$} \\
\hline & $\begin{array}{c}1993 \\
(1) \\
\end{array}$ & $\begin{array}{c}1995 \\
(2) \\
\end{array}$ & $\begin{array}{c}1993 \\
(3) \\
\end{array}$ & $\begin{array}{c}1995 \\
(4) \\
\end{array}$ & $\begin{array}{c}1993 \\
(5) \\
\end{array}$ & $\begin{array}{c}1995 \\
(6) \\
\end{array}$ \\
\hline Market share $1-5 \%$ & $\begin{array}{l}-168 \\
(130)\end{array}$ & $\begin{array}{l}-287 \\
(147)\end{array}$ & $\begin{array}{l}-223 \\
(128)\end{array}$ & $\begin{array}{l}-307 \\
(146)\end{array}$ & $\begin{array}{c}55 \\
(88)\end{array}$ & $\begin{array}{c}20 \\
(84)\end{array}$ \\
\hline HMO market share $5-15 \%$ & $\begin{array}{l}-214 \\
(146)\end{array}$ & $\begin{array}{l}-449 \\
(153)\end{array}$ & $\begin{array}{l}-320 \\
(136)\end{array}$ & $\begin{array}{l}-493 \\
(151)\end{array}$ & $\begin{array}{c}106 \\
(105)\end{array}$ & $\begin{array}{c}44 \\
(104)\end{array}$ \\
\hline HMO market share $15-25 \%$ & $\begin{array}{l}-427 \\
(193)\end{array}$ & $\begin{array}{l}-632 \\
(208)\end{array}$ & $\begin{array}{l}-336 \\
(164)\end{array}$ & $\begin{array}{l}-633 \\
(198)\end{array}$ & $\begin{array}{c}-91 \\
(180)\end{array}$ & $\begin{array}{c}1 \\
(179)\end{array}$ \\
\hline HMO market share $\geq 25 \%$ & $\begin{array}{l}-433 \\
(208)\end{array}$ & $\begin{array}{l}-825 \\
(228)\end{array}$ & $\begin{array}{l}-452 \\
(185)\end{array}$ & $\begin{array}{l}-841 \\
(217)\end{array}$ & $\begin{array}{c}19 \\
(174)\end{array}$ & $\begin{array}{c}16 \\
(180)\end{array}$ \\
\hline $\begin{array}{l}\mathrm{N} \\
\mathrm{R}^{2}\end{array}$ & $\begin{array}{c}707 \\
0.456\end{array}$ & $\begin{array}{c}707 \\
0.374\end{array}$ & $\begin{array}{c}707 \\
0.193\end{array}$ & $\begin{array}{c}707 \\
0.148\end{array}$ & $\begin{array}{c}707 \\
0.360\end{array}$ & $\begin{array}{c}707 \\
0.327\end{array}$ \\
\hline \multicolumn{7}{|l|}{ Predicted Values } \\
\hline $\begin{array}{l}\text { Market share }<1 \% \\
\text { Market share } 1-5 \% \\
\text { Market share } 5-15 \% \\
\text { Market share } 15-25 \% \\
\text { Market share } \geq 25 \%\end{array}$ & $\begin{array}{l}2236 \\
2068 \\
2021 \\
1809 \\
1803\end{array}$ & $\begin{array}{l}2637 \\
2350 \\
2188 \\
2005 \\
1812\end{array}$ & $\begin{array}{l}1596 \\
1373 \\
1276 \\
1260 \\
1144\end{array}$ & $\begin{array}{l}1984 \\
1677 \\
1491 \\
1350 \\
1143\end{array}$ & $\begin{array}{l}640 \\
695 \\
745 \\
549 \\
659\end{array}$ & $\begin{array}{l}653 \\
673 \\
697 \\
654 \\
669\end{array}$ \\
\hline
\end{tabular}

Note: Robust standard errors in parentheses. The models also control for urbanization, demographics, and area health system characteristics. Predicted values are computed holding other covariates in the models at their sample means. Procedure data from the 1993 survey reflect the number of procedures performed in 1992; data from the 1995 survey reflect procedures performed in 1994. 
Figure 1: Percent of Hospitals with MRI

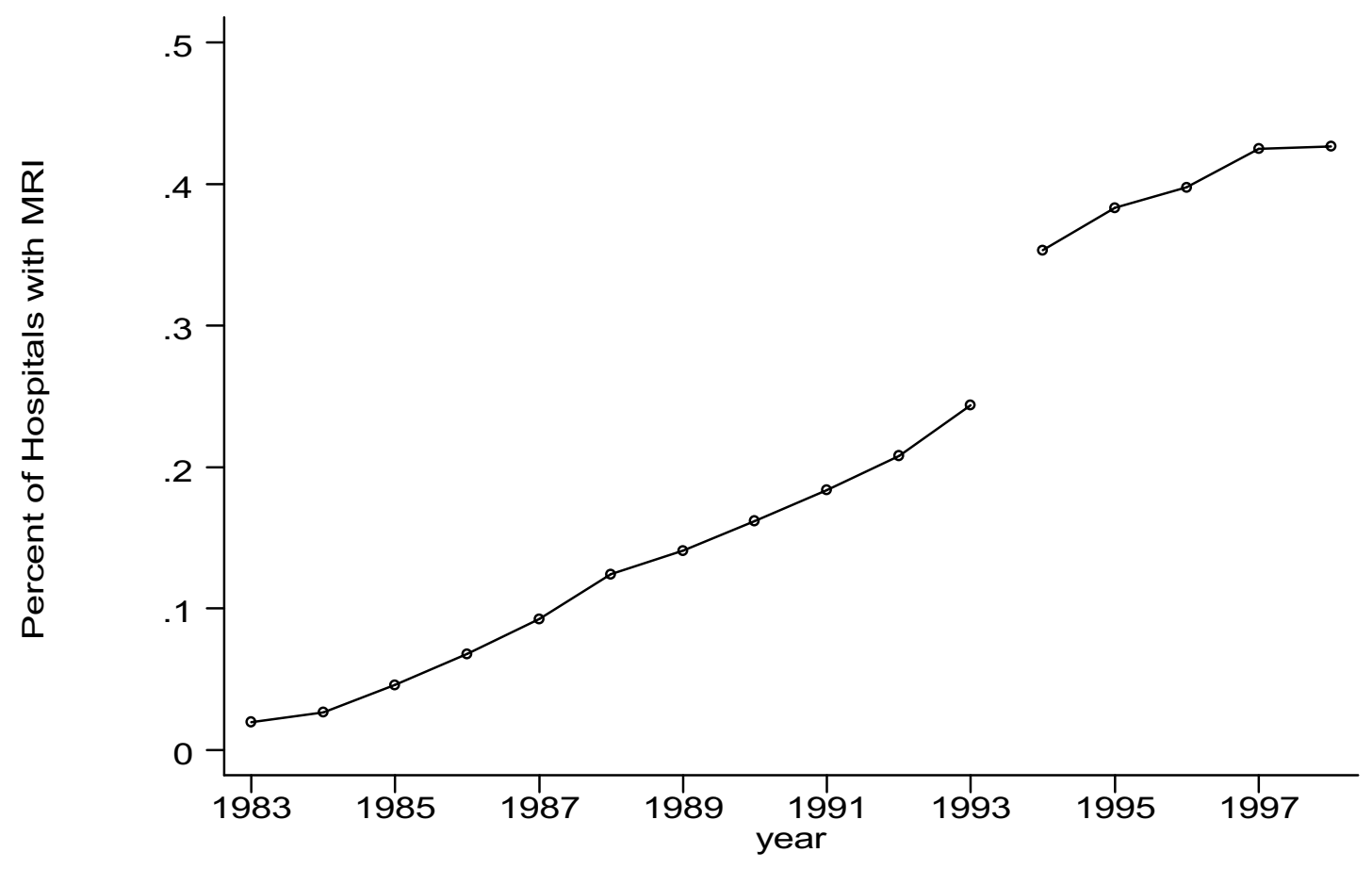

Note: From author's calculations using AHA data. The base sample is non-federal short term general and children's hospitals in non-rural HCSAs. Values for 1983-1993 are Kaplan-Meier estimates of the cumulative adoption probability for hospitals observed in 1983. Values for 1994-1998 are the share of hospitals surveyed each year that reported owing or providing MRI by the hospital or a subsidiary. 
Figure 2: Predicted cumulative adoption probabilities

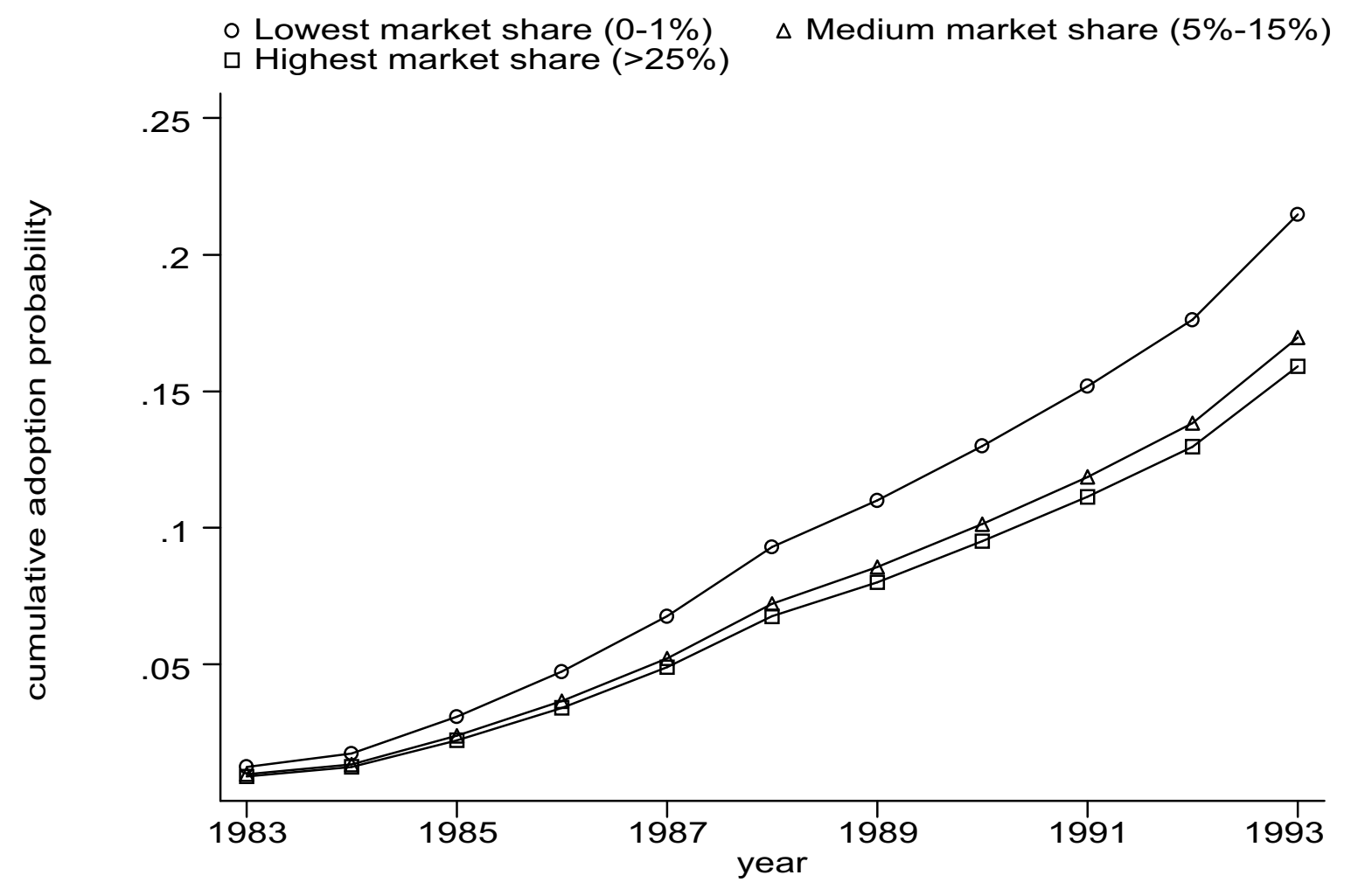

Note: The predicted cumulative adoption probabilities are based on the model in column 1 of Table 3 . 